Copyright (C) The Author(s), 2021. Published by Cambridge University Press for The American Society of International Law. This is an Open Access article, distributed under the terms of the Creative Commons Attribution licence (https:// creativecommons.org/licenses/by/4.0/), which permits unrestricted re-use, distribution, and reproduction in any medium, provided the original work is properly cited.

doi:10.1017/ajil.2021.57

\title{
Complex Designers and Emergent Design: Reforming the InVEstment TREATY SySTEM
}

\author{
By Anthea Roberts* and Taylor St John**
}

\section{ABSTRACT}

How do actors undertake institutional design in complex systems? Scholars recognize that many international regimes are becoming increasingly complex. Yet relatively little is known about how actors design or redesign institutions amid this complexity. As participant-observers in the UN negotiations on investment treaty reform, we have watched state offcials and other participants grapple with this question for several years. To help explain what we have observed, we conceptualize these participants as complex designers - actors who seek to design and redesign institutions within complex adaptive systems. We then formulate three emergent design principles that seem to guide their approach as they aim to create: flexible structures, balanced content, and adaptive management processes. In a dynamic era marked by unpredictability, division, and complex transnational challenges, we believe these concepts may prove to be increasingly relevant in global governance.

\section{INTRODUCTION}

How do actors undertake institutional design in complex systems? Scholars recognize that many international regimes are becoming increasingly complex. ${ }^{1}$ Yet relatively little is known about how actors design or redesign institutions amid this complexity. As

* Professor, School of Regulation and Global Governance, Australian National University, Australia (anthea. roberts@anu.ed.au). Anthea attends UNCITRAL Working Group III as an observer from the Australian National University. She was previously a member of the Australian delegation but has always acted and written in her independent academic capacity.

** Lecturer, School of International Relations, University of St Andrews, Scotland (taylor.stjohn@st-andrews. ac.uk). She attends UNCITRAL Working Group III as an observer from iCourts, University of Copenhagen. The authors thank Brock Burton, Isabella Cuervo-Lorens, Xinmiao Liu, Susan McLean, and Felicity Tepper for excellent research assistance. Support for writing this Article came from the Norwegian Research Council through its FRIPRO scheme, project number 276009, and the ANU Futures Scheme. Funding to follow the UNCITRAL Working Group comes from a capacity building project funded by the Australian Department of Foreign Affairs and Trade, which has enabled us to attend meetings and transcribe the sessions.

${ }^{1}$ As suggested by the growth in scholarship on regime complexes. A regime complex is "an array of partially overlapping and non-hierarchical institutions governing a particular issue-area." Kal Raustiala \& David G. Victor, The Regime Complex for Plant Genetic Resources, 58 InT'L ORG. 277, 278-79 (2004); see also Karen J. Alter \& Sophie Meunier, The Politics of International Regime Complexity, 7 PersP. Pol. 13 (2009); Robert O. Keohane \& David G. Victor, The Regime Complex for Climate Change, 9 Persp. Pol. 7 (2011); Kenneth W. Abbott, The Transnational Regime Complex for Climate Change, 30 Env't \& Plan. C: Gov't \& Pol'y 571 (2012); Karen J. Alter \& Kal Raustiala, The Rise of International Regime Complexity, 14 AnN. Rev. L. \& Soc. SCI. 329 (2018). 
participant-observers in the UN negotiations on investment treaty reform, we have watched state officials and other participants grapple with this question for several years. How should we conceptualize these actors who seek to redesign while keenly aware that they are operating within a complex and dynamic system? What principles seem to guide their design approach?

The investment treaty system is increasingly understood as a complex adaptive system or regime complex. ${ }^{2}$ Joost Pauwelyn harnessed insights from complexity science to explain how the investment treaty system gradually evolved from a series of small, historically contingent, and at times accidental steps, and now operates as a largely decentralized system that nonetheless gives rise to emergent patterns on issues like repeat appointments and quasi-precedents. ${ }^{3}$ Others have argued that complexity theory can afford insight into other areas of international law, including trade and environmental law. ${ }^{4}$ Although complexity theory remains on the margins of international law and international relations, ${ }^{5}$ there is a growing trend toward analyzing international regimes as complex adaptive systems. ${ }^{6}$

But where do designers fit within this turn to complexity theory? In short, they typically do not. Complex systems research represents an attempt to understand patterns that emerge in decentralized systems despite the lack of an "omniscient designer." Complicated machines are designed; complex ecologies evolve. In Pauwelyn's words, the investment treaty system "was not rationally designed or entered into at one given point in time" and "cannot be explained by a singular motive, agent or plan .... There is no single creator, plan or deliberate design." Rather, many elements came together to "organically produce" the investment treaty system - a combination of contingency, path dependency, and competition among actors that continues to drive its operation and development today. ${ }^{8}$

Yet what happens when a group of designers comes together in a conscious attempt to manage the evolution of a complex adaptive system? That is what we see at the negotiations of the United Nations Commission on International Trade Law (UNCITRAL) where states

2 Joost Pauwelyn, At the Edge of Chaos? Foreign Investment Law as a Complex Adaptive System, How It Emerged and How It Can Be Reformed, 29 ICSID REv. 372 (2014); Sergio Puig, International Regime Complexity and Economic Law Enforcement, 17 J. INT'L ECON. L. 3, 491 (2014) (seeing an even larger regime complex encompassing trade and investment agreements); Jonathan Bonnitcha, Lauge N. Skovgaard Poulsen \& Michael Waibel, The Political Economy of the Investment Treaty Regime 6-7 (2017) (characterizing the system as the "investment treaty regime" within a larger "investment regime complex").

3 Pauwelyn, supra note 2 , at 372.

${ }^{4}$ See, e.g., Jean Frédéric Morin, Joost Pauwelyn \& James Hollway, The Trade Regime as a Complex Adaptive System: Exploration and Exploitation of Environmental Norms in Trade Agreements, 20 J. INT'L Econ. L. 365 (2017); Rakhyun E. Kim \& Brendan Mackey, International Environmental Law as a Complex Adaptive System, 14 INT'L Envtl. Agmts.: Pol. L. \& ECON. 5 (2014).

${ }^{5}$ Antoine Bousquet \& Simon Curtis, Beyond Models and Metaphors: Complexity Theory, Systems Thinking and International Relations, 24 CAmbridge Rev. INT'L AfF. 44 (2011) (complexity theory "continues to stubbornly remain on the margins" of IR theorizing); Pauwelyn, supra note 2, at 375 (noting that few studies have applied complexity theory to law, let alone international law).

${ }^{6}$ See, e.g., Thomas Oatley, Toward a Political Economy of Complex Interdependence, 25 EUR. J. INT'L REL. 957 (2019); Amandine Orsini, et al., Forum: Complex Systems and International Governance, 22 InT'L STUD. REV. 1008 (2020); Robert Jervis, System Effects: Complexity in Political and Social Life (1997); Oran R. Young, Regime Dynamics: The Rise and Fall of International Regimes, 36 Int'L Org. 277 (1982); Oran R. Young, Institutional Dynamics: Emergent Patterns in International Environmental Governance (2010).

7 John H. Miller \& Scott E. Page, Complex Adaptive Systems: An Introduction to Computational Models of Social Life xvii (2007).

${ }^{8}$ Pauwelyn, supra note 2 , at 374 . 
and other actors have been meeting since 2017 to consider whether and how to reform investor-state dispute settlement (ISDS). ${ }^{9}$

The UNCITRAL reform process was initially supported by the European Union with the aim of creating a multilateral investment court to replace ISDS. ${ }^{10}$ It soon became clear, however, that no single reform would win out because, while many states agreed ISDS needed to be reformed, they disagreed on how. Some states wanted to pursue reforms to improve ISDS, others sought to replace ISDS with an international court, or some proposed paradigm-shifting reforms to replace investment treaties and international investor-state claims altogether, while others supported a combination of these reform approaches. ${ }^{11}$

The UNCITRAL process has been controversial. On one side, some prominent arbitrators have criticized the process as misguided and going too far. ${ }^{12}$ They view ISDS as a good system that has been unfairly maligned and they warn that the alternatives are deeply problematic for the rule of law and development. On the other, numerous non-governmental organizations (NGOs) and academics have objected that the process lacks ambition and does not go far enough. ${ }^{13}$ By limiting the mandate largely to procedural issues, they say, the process has missed the opportunity to deal with more problematic substantive issues.

In 2021, UNCITRAL approved a work plan to move forward on ISDS reform by pursuing a range of procedural and structural reform options, leaving most substantive issues off the agenda for now but with the possibility of future inclusion. ${ }^{14}$ The work plan proceeds on the assumption that these reforms will be brought together in a multilateral instrument that gives states the choice of which reforms to accept and with respect to which treaties. ${ }^{15}$

\footnotetext{
${ }^{9}$ We refer to the state officials participating in the Working Group as negotiators, even though these officials have not been engaged in formal negotiations during all stages of the process. We use the terms actors or participants to include all individuals and organizations participating in the Working Group, even if they do not represent a state. We include individuals representing the European Union as negotiators, since their participation closely approximates that of states.

${ }^{10}$ We examine the choice for UNCITRAL as the forum in Anthea Roberts \& Taylor St John, The Originality of Outsiders: Innovation in the Investment Treaty System (manuscript on file with the authors).

${ }^{11}$ Anthea Roberts, Incremental, Systemic, and Paradigmatic Reform of Investor-State Arbitration, 112 AJIL 410 (2018).

12 See, e.g., Judge Charles N. Brower \& Jawad Ahmad, Why The "Demolition Derby" That Seeks To Destroy Investor-State Arbitration?, 91 S. CAL. L. Rev. 1139 (2018); Judge Stephen Schwebel, The Proposals of the European Commission for Investment Protection and an Investment Court System: Remarks by Judge Stephen M. Schwebel of May 17, 2016, at Sidley Austin, Washington, D.C. (May 17, 2016) (transcript available at http://isds blog.com/wp-content/uploads/sites/2/2016/05/THEPROPOSALSOFTHEEUROPEANCOMMISSION.pdf).

${ }^{13}$ Lise Johnson \& Lorenzo Cotula, Guest Post: Pragmatism and Flexibility in UNCITRAL Working Group III: Too Much of a Good Thing?, INT'L ECON. L. \& POL'y (Feb. 5, 2020), at https://ielp.worldtradelaw.net/2020/02/guestpost-pragmatism-and-flexibility-in-uncitral-working-group-iii-too-much-of-a-good-thing.html; Bart-Jaap Verbeek, The Limitations of the UNCITRAL Process on ISDS Reform, SOMO (Oct. 30, 2018), at https://www.somo.nl/thelimitations-of-the-uncitral-process-on-isds-reform.

${ }^{14}$ Note by the Secretariat: Workplan to Implement Investor-State Dispute Settlement (ISDS) Reform and Resource Requirements, UNCITRAL Working Group III (Investor-State Dispute Settlement Reform) Fortieth Session (resumed), UN Doc. A/CN.9/WG.III/WP.206 (May 2021), available at http://undocs.org/en/A/CN. 9/WG.III/WP.206.

${ }^{15}$ See Multilateral Instrument on ISDS Reform: Possible Reform of Investor-State Dispute Settlement (ISDS), UNCITRAL Working Group III (Investor-State Dispute Settlement Reform) Thirty-Ninth Session, March-April 2020, UN Doc. A/CN.9/WG.III/WP.194, at https://undocs.org/en/A/CN.9/WG.III/WP.194.
} 
This approach is modeled on recent multilateral conventions in tax (the "Multilateral Instrument") and transparency in arbitration (the "Mauritius Convention"). ${ }^{16}$

How did we get here? Why did the Working Group opt by consensus to move forward with a flexible, adaptable, and evolutionary approach to reform? Having followed this process from the beginning, we have observed that, in addition to the divided views detailed above, the UNCITRAL participants understand the current ISDS system to be complex yet are seeking to design and redesign amid that complexity. ${ }^{17}$ They see themselves as conscious designers but recognize that they cannot completely control the system in which they are intervening or fully predict the consequences of their interventions.

To help explain and theorize what we have observed, we conceptualize these UNCITRAL participants as complex designers and formulate a series of emergent design principles that seem to guide their approach in the reform negotiations.

In formulating these concepts, we employ an abductive sensemaking method that braids together insights from participant-observation at UNCITRAL with complexity theory. We do not argue that negotiators at UNCITRAL will or should adopt these emergent design principles in the final version of the reforms; the aim of this Article is neither predictive nor normative. Instead, we crystallize the underlying logic that we see at work in the UNCITRAL process so far, drawing on complexity theory to yield new frameworks for illuminating what we observe. ${ }^{18}$

In Part I, we outline our methods and position our contribution in the literature. In Part II, we introduce complexity theory and address concerns about applying it to institutions populated by sophisticated, strategic actors. We then turn to the UNCITRAL context and explain how participants at UNCITRAL approach the investment treaty system as a complex adaptive system. They see a system made up of many actors (states, investors, international organizations, law firms, NGOs) and structures (treaties, institutions, awards) that reflect diverse views and interact in myriad ways, often with unpredictable outcomes. ${ }^{19}$

In Part III, we focus on the agency of these actors, conceptualizing participants at UNCITRAL as complex designers - actors who seek to design and redesign institutions within complex adaptive systems. The complex designers we see at UNCITRAL face unpredictability

${ }^{16}$ OECD, Multilateral Convention to Implement Tax Treaty Related Measures to Prevent Base Erosion and Profit Shifting (2021), at https:/www.oecd.org/tax/treaties/multilateral-convention-to-implement-tax-treatyrelated-measures-to-prevent-beps.htm; UNCITRAL, United Nations Convention on Transparency in Treatybased Investor-State Arbitration (Dec. 10, 2014), at https://uncitral.un.org/en/texts/arbitration/conventions/ transparency.

${ }^{17}$ UNCITRAL is not the only place in which redesign is occurring in the investment treaty system, but it gains the most attention and governmental time currently. Other fora include ICSID, which is reforming its rules, and UNCTAD, which is developing a menu of substantive reform options. See ICSID, About the ICSID Rule Amendments, at https://icsid.worldbank.org/resources/rules-and-regulations/amendments/about; see UNCTAD, UNCTAD's Reform Package for the International Investment Regime (2018), available at https://investmentpolicy. unctad.org/uploaded-files/document/UNCTAD_Reform_Package_2018.pdf.

${ }^{18}$ Our approach is consistent with the idea of "emergent analytics," meaning "analytics that the researchers have not themselves brought to the project on account of their analytic priors, but which emerge from the investigation in terms of both revealed facts and new concepts necessary to explain and respond to those facts." Victoria Frances Nourse \& Gregory C. Shaffer, Empiricism, Experimentalism, and Conditional Theory, 67 SMU L. REV. 141, 152 (2014). See also Gregory Shaffer, The New Legal Realist Approach to International Law, 28 LeIDEN J. INT'L L. 189 (2015).

${ }^{19}$ Andreas Duit \& Victor Galaz, Governance and Complexity-Emerging Issues for Governance Theory, 21 Governance: Int'l J. Pol'y, Admin., \& Inst. 311, 317 (2008). 
and ongoing change, but still aspire to design or redesign institutions that will deliver on their substantive goals over time. In our observation, they function like landscape architects who focus on both episodic design and adaptive management. Like architects, they attempt to design structures that respond to but also shape the users who will inhabit them. Like gardeners, they consider the environment in deciding what to seed and when, being mindful of the need to tend to their plants and calibrate their caregiving in light of changing conditions.

In Part IV, we develop a series of emergent design principles that we discern underlying the approach of negotiators at UNCITRAL, which we see as key to the evolutionary and experimental approach to reform that they have adopted. We highlight three principles in particular: flexible structures, balanced content, and adaptive management processes. ${ }^{20}$

We argue that there is a coherence and logic underlying the negotiators' approach and explain how their approach aligns with normative recommendations made by applied complexity theorists. While we do not argue for or against any reform or reform package under discussion, we see value in evolutionary, experimental approaches and in emergent designs generally in turbulent fields characterized by diverse preferences.

In the conclusion, we consider the wider applicability of complex designers and emergent design. Examples from climate change and trade suggest the potential for these concepts to serve as a framework for understanding institutional design in complexity more generally. In a dynamic era marked by unpredictability, division, and complex transnational challenges, we believe these concepts may prove to be increasingly relevant in global governance.

\section{ConteXt And Methods}

\section{A. Participant Observation and Abductive Sensemaking Methods}

Our approach builds on the research of Susan Block-Lieb and Terence Halliday, who studied UNCITRAL as "participant-observer insiders" and used their close observations to produce general theoretical insights about international organizations as lawmakers. ${ }^{21} \mathrm{We}$ have been participant-observers in UNCITRAL Working Group III throughout its work on ISDS reform, from 2017 to the present. We attend as academic observers and do not formally advise any government or actor. ${ }^{22}$ Like other scholars who have drawn on close observation for theory building, we aim at conveying how actors perceive their world and act within it by generating new framings. ${ }^{23}$

\footnotetext{
${ }^{20}$ The notion of adaptive management emerged in relation to the management of ecosystems, but it is starting to be applied more broadly, including to complex social systems. It finds its origin in CraWFORD STANLEY Holling, Adaptive Environmental Assessment and Management (1978).

${ }^{21}$ Susan Block-Lieb \& Terence C. Halliday, Global Lawmakers: International Organizations in the Crafting of World Markets 9 (2017).

${ }^{22}$ As noted above, Anthea attends UNCITRAL Working Group III as an observer from the Australian National University. She was previously a member of the Australian delegation but has always acted and written in her independent academic capacity. Taylor attends as an observer from iCourts, University of Copenhagen.

${ }^{23}$ Other examples of scholars drawing on close observation for theory building include Michael Barnett and Martha Finnemore's book conceptualizing international organizations as bureaucracies, and Robert Putnam's theory of negotiations as two-level games. See Michael Barnett \& Martha Finnemore, Rules for the World: International Organizations in Global Politics (2004); Robert Putnam, Diplomacy and Domestic Politics: The Logic of Two-Level Games, 42 INT'L OrG. 427 (1988).
} 
We sit in the negotiating room throughout the formal deliberations, listening and taking notes. We also have audio recordings of each negotiating session. We collect the formal and informal documents that are made available during the negotiating sessions, including lists of participants, informal summaries, and promotional materials. During the breaks, and in informal settings, we converse with a wide range of negotiators and other actors in the room, including representatives of civil society, international organizations, and private-sector groups. We have supplemented these informal interactions with formal interviews throughout the proceedings, though all material from unofficial discussions is unattributed given the ongoing nature of the process.

These modes of information gathering and exchange fall within the broad tradition of ethnographic methods, which are characterized by sustained observation of a particular site with access to, and repeated interactions with, key actors. Researchers embed themselves in actors' worlds to understand and conceptualize these worlds. The analytical insights emerge from a process that begins with "an open-minded immersion into the field." 24 This process involves establishing rapport with actors and developing empathetic understandings of these actors and how they see the world. In our context, this approach meant prioritizing listening and building trust with participants, so that we could hear how they perceive the negotiations and related concerns, such as their constraints, mandates, audiences, aims, and strategies.

Through repeated interactions over four years, our understanding of these participants and how they approach the negotiations deepened. Our process was abductive and iterative: listening to how participants, particularly negotiators, describe the system and their strategies came first; then comparing this description with existing conceptualizations; then building different conceptualizations when needed; then asking negotiators how particular conceptualizations fit with their understandings; and finally refining our conceptualizations. ${ }^{25}$ This iterative approach to theory building is neither inductive nor deductive, but is consistent with the process of sensemaking in complex fields, which involves a two-way process of fitting data into frames and fitting frames around the data. ${ }^{26}$ This approach also recognizes the researcher as a participant operating inside an open system rather than as abserver sitting outside a closed system looking in.

We employ this abductive method during the negotiations by writing near-contemporaneous blogs about the process. After observing the negotiations and talking to various actors about what has occurred, we draft blogs that explain what we are observing. We often frame these observations within a broader context of either the process or different theoretical literatures. After a week of negotiations is completed, but before publishing these blogs, we

\footnotetext{
${ }^{24}$ Jonas Bens \& Larissa Vetters, Ethnographic Legal Studies: Reconnecting Anthropological and Sociological Traditions, 50 J. Legal Pluralism \& Unofficial L. 239, 249 (2018).

${ }^{25}$ On abductive theorizing, see Derek Layder, Sociological Practice: Linking Theory and Social Research (1998); Iddo Tavory \& Stefan Timmermans, Abductive Analysis: Theorizing Qualitative Research (2014); Stefan Timmermans \& Iddo Tavory. Theory Construction in Qualitative Research: From Grounded Theory to Abductive Analysis, 30 SOCIO. THEORY 167 (2012).

${ }^{26}$ On the meaning of sensemaking, see KarL E. Weick, Sensemaking in Organisations (1995); Karl E. Weick, Kathleen M. Sutcliffe \& David Obstfeld, Organizing and the Process of Sensemaking, 16 OrG. SCI. 409 (2005). On the importance of sensemaking in complex systems, see Cynthia Kurtz \& David Snowden, The New Dynamics of Strategy: Sense-Making in a Complex and Complicated World, 42 IBM Sys. J. 462 (2003). On sensemaking as a twoway process of fitting data into a frame and fitting a frame around the data, see Gary Klein, Brian Moon \& Robert R. Hoffman, Making Sense of Sensemaking II: A Macrocognitive Model, 21 IEEE InTELLIGENT SYSTEMS 88 (2006).
} 
share them for comment with a diverse group of participants to gain different perspectives on what happened during the week. We recognize that this dialogue is shaped by how actors perceive us and we update our framings in light of the diverse feedback we receive. The publication of these blogs during the ongoing UNCITRAL process means that they have become part of the group's sensemaking process, which makes us participant-observers, not just observers.

Although our conceptualizations and analyses are our own, in important ways they are also cogenerated. We put forward the ideas in scholarly form, but they emerge from a dialogue with participants in the process_ a process sometimes described as "para-ethnography." 27 Adopting a similar approach in the trade field, Gregory Shaffer describes it as "the study of social processes through interviewing, and even working with, practitioners 'who are themselves engaged in quasi-social scientific 'studies' of the same processes' in an effort to understand and respond to them. In this way, the interviews, in part, can be viewed as 'collaborations' in the sense of forays into 'making sense' of developments." 28

We often draw on theories from outside the room to help explain or contextualize a particular dynamic we observe inside the room. ${ }^{29}$ In doing so, we communicate dynamics inside the room to an outside audience and also provide new frames through which participants in the room can reflect on the process. Participants in the room sometimes adopt our framings and language in the negotiations and sometimes reject them, including for strategic reasons. We respond by updating our conceptualizations and terminology in light of developments, as this is an iterative sensemaking process. ${ }^{30}$

We used this abductive mode to develop the ideas in this Article about complex designers and emergent design principles. The advantages of this method stem from proximity: close observation leads to better conceptualizations of how actors see themselves and the reform process, as well as to insights that would be impossible to gain through other means. The downsides of this method, however, also stem from proximity: close and empathetic observation means less critical distance from the actors and the process. ${ }^{31}$ Yet this form of

${ }^{27}$ Douglas R. Holmes \& George E. Marcus, Para-Ethnography, in The SAge Encyclopedia of Qualitative Research Methods: M-W, Vol. II, 595 (Lisa M. Given ed., 2008) (Para-ethnography “propos[es] an analytical relationship in which we and our subjects - keenly reflexive subjects — can experiment collaboratively with the conventions of ethnographic inquiry. This methodological stance demands that we treat our subjects as epistemic partners who are not merely informing our research but who participate in shaping its theoretical agendas and its methodological exigencies. By treating our subjects as collaborators, as epistemic partners, our analytical interests and theirs can be pursued simultaneously, and we can share insights and thus develop a common analytical exchange.").

28 Gregory Shaffer, Emerging Powers and the World Trading System: The Past and Future of INTERNATIONAL ECONOMIC LAW xv (2021) (internal quotation marks omitted), see also xvi-xvii.

${ }^{29}$ See, e.g., Anthea Roberts \& Taylor St John, UNCITRAL and ISDS Reform (Online): Crossing the Chasm, EJIL: TALK! (Feb. 17, 2021), at https://www.ejiltalk.org/uncitral-and-isds-reform-online-crossing-the-chasm (drawing on ideas about the diffusion of innovations to explain the importance of the group moving to drafting); Anthea Roberts \& Taylor St John, UNCITRAL and ISDS Reform: Plausible Folk Theories, EJIL:TALK! (Feb. 13, 2020), at https://www.ejiltalk.org/uncitral-and-isds-reform-plausible-folk-theories (discussing what questions are asked and not asked in the process through the concept of plausible folk theories).

${ }^{30}$ For an example of how the language from these blogs was picked up, politicized, and rejected by states within the process, see Anthea Roberts \& Taylor St John, UNCITRAL and ISDS Reform: Battles Over Naming and Framing, EJIL:TALK! (Apr. 30, 2019), at https://www.ejiltalk.org/uncitral-and-isds-reforms-battles-over-naming-and-framing.

${ }^{31}$ Holmes \& Marcus, supra note 27, at 596 ("Para-ethnography is, on the one hand, premised on the central intellectual imperative of classical anthropological ethnography ... to evoke and to reproduce the native point of 
knowledge production is recognized as an important and experimental contribution to ethnographic methods that is occurring various domains, including science, law, finance, politics, and architecture, in the early twenty-first century. ${ }^{32}$

\section{B. Investment Law Literature: Cooperation and Continuity}

Scholarship on the investment treaty system has burgeoned in recent decades. It has applied increasingly diverse theories and methods and expanded the boundaries of knowledge about the investment treaty system in several directions. One direction has been to examine how officials think about the investment treaty system, including the purposes they ascribe to investment treaties when negotiating them and to what extent the investment treaty system serves those purposes. Scholarship examining the way officials think about the investment treaty system has emphasized two themes: cooperation and continuity. Many scholars elaborate both but place more emphasis on one or the other. Setting out the two themes individually is helpful for situating our contribution.

The first theme foregrounds the role of cooperation in the investment treaty system. That is, it assumes that states and other actors sign investment treaties or delegate dispute resolution because they believe it will help them reach desired aims. These aims vary by actor, over time, and by circumstance, but scholars have identified a few goals as enduring justifications for the investment treaty system. They include protecting and/or promoting foreign investment, ${ }^{33}$ strengthening domestic legal systems, ${ }^{34}$ and depoliticizing disputes by removing them to the legal sphere. ${ }^{35}$ Scholars debate which justifications should underpin the system normatively and the extent that the system delivers on these goals descriptively. ${ }^{36}$

The cooperation theme corresponds broadly with institutionalist theory. Institutionalist arguments vary along a spectrum: one end is marked by explanations with strong assumptions of full rationality and efficient institutional design; these assumptions are then loosened by degrees until reaching the other end of the spectrum, which is characterized by bounded rationality and inefficient designs that often produce unintended consequences.

Many early explanations of the investment treaty system took as their starting point that states are rational actors that can predict the consequences of signing investment treaties and

view. On the other hand, it is predicated on relationships of complicity with our subjects — a state of ambiguity and improper seeming alliance - that now pervade ethnographic encounters establishing new possibilities for creating anthropological knowledge.”).

${ }^{32}$ Holmes \& Marcus, supra note 27, at 595-96.

33 Bonnitcha, Skogatrd Poulsen \& Waibel, supra note 2, at 154-80 and 207-220.

34 Mavluda Sattorova, The Impact of Investment Treaty Law on Host States: Enabling Good GOVERNANCE? (2018).

35 Geoffrey Gertz, Srividya Jandhyala \& Lauge N. Skovgaard Poulsen, Legalization, Diplomacy, and Development: Do Investment Treaties De-politicize Investment Disputes?, 107 World Dev. 239, 240 (2018); Martins Paparinskis, Limits of Depoliticisation in Contemporary Investor-State Arbitration, in SELECT Proceedings of the European Society of International Law (James Crawford ed., 2010); Ibrahim F. I. Shihata, Towards a Greater Depoliticization of Investment Disputes: The Roles of ICSID and MIGA, 1 ICSID REV. For. INV. L.J. 25 (1986).

${ }^{36}$ Gus Van Harten, Five Justifications for Investment Treaties: A Critical Discussion, 2 Trade L. \& Dev. 19 (2010); Robert Howse, International Investment Law and Arbitration: A Conceptual Framework, in International LaW and Litigation: A Look into Procedure (Hélène Ruiz-Fabri ed., 2019); Sergio Puig, Recasting ICSID's Legitimacy Debate: Towards a Goal-Based Empirical Agenda, 36 FordHAm InT'L L.J. 465 (2013); Jason Webb Yackee, Pacta Sunt Servanda and State Promises to Foreign Investors Before Bilateral Investment Treaties: Myth and Reality, 32 Fordham InT'L L.J. 1550 (2008). 
can design them to maximize mutual gain. ${ }^{37}$ With refinements, substantial research along these lines continues. ${ }^{38}$ For instance, Alan Sykes explains:

The economic explanation for IIAs [international investment agreements] begins with the premise that counterparties must expect to be better off with IIAs than without them or they would not agree to them. An economic theory of IIAs thus necessarily entails a search for sources of mutual gain—the "efficiencies" from concluding them. ${ }^{39}$

Although Sykes does not claim that investment treaties promote efficiency flawlessly, he does claim that "properly crafted and interpreted treaty provisions can ameliorate a range of inefficiencies that would arise in their absence, and that central features of existing IIAs have their genesis in this economic logic." ${ }^{0} 0$ Research along these lines has encountered serious challenges in light of evidence that investment treaties may not ameliorate the inefficiencies as expected by some scholars, notably that investment flows may not correlate with investment treaties. If there is no additional investment, scholars began to ask, why do states sign these treaties?

Later scholars answer this question by loosening the assumptions that underpin the rational choice explanations. For instance, Lauge Poulsen loosens the assumption of rationality to allow for cognitive biases, arguing that officials often systematically underestimate the costs and overestimate the benefits of signing investment treaties. ${ }^{41}$ Other scholars, including Taylor St John, emphasize the role played by international organizations in framing relevant decisions, and draw attention to processes that unfold over time and shape officials' decisions regarding the investment treaty system, like path dependence and feedback effects. ${ }^{42}$

When it comes to ISDS reform debates, these approaches focus attention on a particular line of questions: What goals should the investment treaty system serve and to what extent does it serve those goals? If it does not serve those goals, should it be replaced by other institutional arrangements that will? Sergio Puig and Gregory Shaffer's article exemplifies this

\footnotetext{
37 Andrew T. Guzman, Why LDCs Sign Treaties that Hurt Them: Explaining the Popularity of Bilateral Investment Treaties, 38 VA. J. INT'L L. 639 (1998). Zachary Elkins, Andrew T. Guzman \& Beth A. Simmons, Competing for Capital: The Diffusion of Bilateral Investment Treaties, 1960-2000, 60 INT'L OrG. 811 (2006).

${ }^{38}$ Yoram Z. Haftel, Ratification Counts: US Investment Treaties and FDI Flows into Developing Countries, 17 Rev. InT'L Pol. ECon. 348 (2010); Tim Büthe \& Helen V. Milner, Foreign Direct Investment and Institutional Diversity in Trade Agreements: Credibility, Commitment, and Economic Flows in the Developing World, 1971-2007, 66 World POL. 88 (2014).

39 Alan O. Sykes, The Economic Structure of International Investment Agreements with Implications for Treaty Interpretation and Design, AJIL 482, 483 (2019).

${ }^{40} I d$. at 483-484.

${ }^{41}$ Lauge N. Skovgaard Poulsen, Bounded Rationality and Economic Diplomacy: The Politics of Investment Treaties in Developing Countries (2015).

42 Taylor St John, The Rise of Investor-State Arbitration: Politics, Law, and Unintended CONSEquences (2018). Generally on the roles of norms and beliefs in the system's growth, see Srividya Jandhyala, Witold J. Henisz \& Edward D. Mansfield, Three Waves of BITs: The Global Diffusion of Foreign Investment Policy, 55 J. Conflict Resol.1047-73 (2011) (observing that the second wave of BITs was driven by states showing adherence to what had become a global standard or norm); Jason Webb Yackee, Are BITs Such a Bright Idea? Exploring the Ideational Basis of Investment Treaty Enthusiasm, 12 U.C. DAVIS J. INT'L L. \& POL'y 195 (2005-2006) (emphasizing the ideational basis of the BIT phenomenon); Julia Calvert, Constructing Investor Rights? Why Some States (Fail to) Terminate Bilateral Investment Treaties, 25 Rev. InT'L POL. ECON. 75 (2018) (demonstrating how officials' ideas and beliefs shaped investment treaty policy).
} 
approach; they first clarify the goals that the investment treaty system is designed to serve before comparing how well several different institutional arrangements serve them. ${ }^{43}$

The second theme stresses the role of power and centers distributive questions about who benefits and who loses from the investment treaty system. An important aspect of this work is describing and denouncing continuities between imperialism and the contemporary investment treaty system. As Olabisi Akinkugbe summarizes it: at the "heart of the critique" is "rejection of the post-colonial continuities of the technologies of governance and the asymmetry that characterizes foreign investor relations in the host states." 44

Many scholars have documented continuities between empire and investment treaties and observed an "enduring contest of interests between capital-exporting states and host states, investors, and local communities." ${ }^{45}$ In this view, current controversies are not new but are manifestations of older struggles and power dynamics that have dominated international investment law since the nineteenth century, if not earlier. Some scholars regard these struggles as characteristic of capitalism; formal imperialism was just one manifestation of capitalism's boundless tendency toward expansion, and patterns of argumentation in international law that justified imperialism persist today. ${ }^{46}$

Approaches that foreground continuity see a clash between powerful actors seeking investment protection and other actors that endures despite changing political arrangements and ideas. After outlining this continuing contest, Muthucumaraswamy Sornarajah argues that the investment treaty system's growth in the 1990s was driven by powerful actors' adoption of neoliberalism, which reflected an ideological preference for liberalization of markets, trade, and investment. ${ }^{47}$ In his telling, powerful states promoted the investment treaty system with the instrumental purpose of building a law that "served the specific purpose of investment protection" and ensured that "the purpose of investment protection could not be diluted by other considerations." 48

In this view, the investment treaty system has long been devoted to investment protection while neglecting competing interests such as human rights and protection of the environment or other public interests. One consequence emphasized by scholars is the empowerment of some actors at the expense of others, such as by conferring both rights and remedies on

43 Sergio Puig \& Gregory Shaffer, Imperfect Alternatives: Institutional Choice and the Reform of Investment Law, 112 AJIL 361 (2018) (observing that the normative goals of the investment treaty system have changed over time but three goals_-fairness, efficiency, and peace-are used to justify the current ISDS model, which they reframe into a single, overarching principle, "accountability under the rule of law").

44 Olabisi D. Akinkugbe, Africanization and the Reform of International Investment Law, 53 CASE W. RES. J. INT'L L. 7 (2021).

45 Kate Miles, The Origins of International Investment Law: Empire, Environment and the Safeguarding of Capital 387 (2013). See also Sundhya Pahuja, Decolonising International Law: Development, Economic Growth and the Politics of Universality 95-171 (2011); Muin Boase, $A$ Genealogy of Censurable Conduct: Antecedents for an International Minimum Standard of Investor Conduct, in International Investment LaW and History (Stephan W. Schill, Christian J. Tams \& Rainer Hofmann eds., 2018); David Schneiderman, The Coloniality of Investment Law (2019), available at https://ssrn.com/ abstract $=3392034$.

${ }^{46}$ Ntina Tzouvala, Capitalism as Civilisation: A History of International Law (2020)

${ }^{47}$ Muthucumaraswamy Sornarajah, Resistance and Change in the International Law on Foreign INVESTMENT 9 (2015).

48 Sornarajah, supra note 47 , at 8 . On to role of private actors in this process, see Nicolás Perrone, Investment Treaties \& The Legal Imagination: How Foreign Investors Play by Their Own Rules (2021). 
investors but not providing local communities with either one. ${ }^{49}$ Another critique is that investment treaties unduly constrain national regulatory autonomy, for example, through claims or potential claims having a chilling effect on regulatory measures aimed at public health or environmental protection. ${ }^{50}$

In ISDS reform debates, approaches that emphasize continuities with empire often concentrate attention on asymmetries and alternative visions: Does the investment treaty system unduly benefit and empower foreign investors at the expense of other actors? If so, should it be dismantled? And what alternative visions for investment governance might exist? Calls for transformation and a radical rethinking of the international economic order are particularly pronounced from scholars associated with Third World Approaches to International Law; contributions to a recent Afronomics symposium exemplify this perspective applied to ISDS reform debates. ${ }^{51}$ There is not one alternative vision but many visions emerging from the Global South; for instance, Fabio Morosini and Michelle Ratton Sanchez Badin approach the Global South as "a laboratory for alternative economic order" and several scholars highlight recent African innovations. ${ }^{52}$

\section{Bridging Academic and Policy Debates}

Despite the many insights produced by the cooperation and continuity approaches, in our capacity as observers at UNCITRAL we have not heard what these academic approaches led us to expect. In fact, we have been struck by a wider disconnect between how the scholarly and policymaking communities perceive the events at UNCITRAL.

The cooperation approach led us to expect that negotiators would actively consider the goals of the investment treaty system and make design decisions in light of these goals. Yet the negotiators rarely discuss the purposes of the investment treaty system and many do not

${ }^{49}$ Nicolás Perrone, The "Invisible" Local Communities: Foreign Investor Obligations, Inclusiveness, and the International Investment Regime, 113 AJIL Unbound 16 (2019); Lorenzo Cotula, Investment Disputes From Below: Whose Rights Matter? Mining, Environment and Livelihoods in Colombia, IIED (July 23, 2020), at https://www.iied.org/investment-disputes-below-whose-rights-matter; Lorenzo Cotula, The New Enclosures? Polanyi, International Investment Law and the Global Land Rush, 34 THIRD WORLD Q. 1605 (2013).

${ }^{50}$ Kyla Tienhaara, Regulatory Chill and the Threat of Arbitration: A View from Political Science, in EvOLUTION IN Investment Treaty LaW And Arbitration 606 (Chester Brown \& Kate Miles eds., 2011); Tarald Laudal Berge \& Axel Berger, Do Investor-State Dispute Settlement Cases Influence Domestic Environmental Regulation? The Role of Respondent State Bureaucratic Capacity, 12 J. InT'L Disp. Settlement 1 (2021).

51 See James Thuo Gathii \& Oblasbisi D. Akinkugbe, Afronomics Law Symposium: Centering Voices from the Global South on Investor-State Dispute Settlement Reform: A Debate, AfronomicsLaw (Sept. 10, 2020), at https://www.afronomicslaw.org/2020/09/07/symposium-introduction-centering-voices-from-the-global-southon-investor-state-dispute-settlement-reform-a-debate. On TWAIL approaches to investment law generally see, Antonius R Hippolyte, Aspiring for a Constructive TWAIL Approach Towards the International Investment Regime, in Foreign Investment Law and Development: Bridging the Gap (Rainer Hofman, Christian J. Tams \& Stephan W. Schill eds., 2015). James Thuo Gathii, Third World Approaches to International Economic Governance, in International LaW and the Third World, Reshaping Justice (Richard Falk, Balakrishnan Rajagopal \& Jacqueline Stevens eds., 2008).

${ }^{52}$ Fabio Morosini \& Michelle Ratton Sanchez Badin, Reconceptualizing International Investment Law from the Global South, in Reconceptualizing International Investment LaW From the Global South 1, 7 (Fabio Morosini \& Michelle Ratton Sanchez Badin eds., 2018). On African innovations, see Akinkugbe, supra note 44; Hamed El-Kady \& Mustaqeem De Gama, The Reform of the International Investment Regime: An African Perspective, 34 ICSID ReV. For. InV. L.J. 482 (2019); Makane Moïse Mbengue, Special Issue: Africa and the Reform of the International Investment Regime: An Introduction, 18 J. WORLD InV. \& TRADE 371 (2017). 
appear to believe they have a mandate to question the system's goals. As we have reflected in our blogs:

We are often asked why the Working Group III debate is bounded. Why are the big questions not being asked? Why are the system's foundational premises not being reexamined in the light of new evidence? Being observers in the room leads us to reframe that question: who has a mandate to ask these sorts of big questions? Many delegates, when asked, emphasize that they have a limited mandate and feel they are constrained by various precedents. ${ }^{53}$

The continuity approach led us to expect the negotiating landscape to be permeated by power and enduring asymmetries, and negotiators to be divided between those seeking stronger investment protection and those with other goals. Of course, power does permeate multilateral negotiations and negotiators know the system's asymmetric history. But in our observations, negotiators view inequalities and asymmetries as part of the terrain on which they work, and define their job as finding ways to achieve their objectives despite differences in resources, status, or experience. Nor do states' histories as capital exporters or importers explain the positions we have seen. There are no coalitions representing the Global North or Global South; instead, we have found a variety of positions among African states, among Latin American states, among North Atlantic states, and among Asian states.

Many in the scholarly community interpret this disconnect as a defect in the UNCITRAL process - a failure to engage with big questions and understand recent scholarship. They recognize that these negotiations represent the first time states have come together multilaterally, in a forum open to all UN member states, to discuss ISDS reform. Yet they view the discussions as starting from a faulty premise since they did not begin from first principles and they are largely limited to procedural issues when, for many academics and representatives of civil society, substantive issues constitute the system's real problems. No matter what the outcome, in this view, the UNCITRAL Working Group has limited imagination and is tinkering at the margins.

Many in the policymaking community interpret this disconnect as a failure of academics to grapple with the constraints of negotiators' roles and the real-world challenges that beset reform processes at UNCITRAL and elsewhere. In this view, academics are often utopians with limited understanding of how change occurs in practice or the obstacles that negotiators face when pushing for change. Saying in an academic paper that investment treaties should place obligations on investors is one thing; figuring out how to achieve such a goal in practice is another. Actors taking this view acknowledge that discussions at UNCITRAL are held within certain bounds, but some see the process as strengthening actors and processes that may lead to more ambitious outcomes in combination and over time.

We seek to bridge this disconnect by explaining what we perceive about the process from inside the room, from a deliberately empathetic posture, to audiences outside the room. We turn to complexity theory to make sense of our observations as it best captures the logic we see at work in the room. Complexity theory does not replace other approaches; it complements them. Each approach captures something important, being useful for some purposes and not for others.

${ }^{53}$ Roberts \& St John, Plausible Folk Theories, supra note 29. 
The complexity approach we outline next is helpful for understanding how actors seek to manage complex systems. In the case of UNCITRAL_ and the contemporary investment treaty system more generally - a defining theme is that states are increasingly (re)asserting their role as managers of that system. This movement and its dynamics are relatively well understood on a unilateral and a bilateral basis. ${ }^{54}$ But how can we understand the way states perform this role multilaterally, often in the presence of profound disagreement, and on many issues simultaneously? This is the "how" that complexity theory helps us to see more clearly.

\section{COMPleXity Theory}

A growing number of scholars are embracing complexity theory as a new paradigm for understanding and analyzing social systems, including international regimes. ${ }^{55}$ Why? In large part it is because complexity theory provides a different way of seeing, one that brings systems and ongoing change to the fore, leading to new questions and tools for analysis. As complexity economist Brian Arthur observes:

It gives a different view, one where actions and strategies constantly evolve, where time becomes important, where structures constantly form and re-form, where phenomena appear that are not visible to standard equilibrium analysis, and where a meso-layer between the micro and the macro becomes important. This view . . gives us a world . . that is organic, evolutionary, and historically-contingent. ${ }^{56}$

What does that mean when applied to the investment treaty system? Using complexity theory as a starting point shifts our focus away from which problems the investment treaty system seeks to address or its power imbalances and distributive consequences. Instead, complexity theory shifts our focus to "how" questions, including how to identify available strategies of change in contexts of disagreement and unpredictability; how to monitor and manage feedback loops and emergent patterns; and how to enable adaptative management over time. It captures the question we see negotiators frequently asking themselves: "How can I intervene in this complex system most effectively?"

\footnotetext{
${ }^{54}$ Rodrigo Polanco, The Return of the Home State to Investor-State Disputes: Bringing Back Diplomatic Protection (2019); Reassertion of Control Over the Investment Treaty Regime (Andreas Kulick ed., 2017); Shifting Paradigms in International Investment Law: More Balanced, Less Isolated, Increasingly Diversified (Steffen Hindelang \& Markus Krajewski eds., 2016); Reshaping the InvestorState Dispute Settlement System: Journeys for the 21st Century (Jean E. Kalicki \& Anna Joubin-Bret eds., 2015); The Role of the State in Investor-State Arbitration (Shaheeza Lalani \& Rodrigo Polanco Lazo eds., 2014); Anne van Aaken, Control Mechanisms in International Investment Law, in THE FoundaTIONS of International Investment Law: Bringing Theory into Practice 409 (Zach Douglas, Joost Pauwelyn \& Jorge E. Viñuales, 2014).

${ }^{55}$ For explanations of complexity as a new paradigm for understanding social sciences, see Orsini, et al., supra note 6, at 1009-10; Fariborz Zelli, Lasse Gerrits \& Ina Möller, Global Governance in Complex Times: Exploring New Concepts and Theories on Institutional Complexity, 6 COMPLexity, GovernanCE \& Networks 1 (2020); Law Public Policies and Complex Systems: Networks in Action (Romain Boulet, Claire Lajaunie \& Pierre Mazzega eds., 2019).

56 W. Brian Arthur, Complexity Economics: A Different Framework for Economic Thought, in COMPLEXITY AND THE ECONOMY 2 (W. Brian Arthur ed., 2015).
} 


\section{A. The Turn to Complexity Theory}

Complexity theory involves the interdisciplinary study of systems that are made up of interconnected parts, which can be natural or human-made. Seeing in systems is foundational for complexity theory, which emphasizes the importance of looking at systems holistically to see patterns that emerge from the (sometimes unpredictable) interaction of various elements. Complex adaptive systems are constituted by the interactions of different actors as well as the structures that emerge from and shape those interactions and actors. ${ }^{57}$ Interactions lead to defining traits of complex systems: feedback, emergence, unpredictability, and nonlinear change. As actors and structures interact, feedback is generated that encourages actors to continue down some paths and not others, amplifying some actions while dampening others, and sometimes wearing grooves into the system that bring about temporary stability. Interactions and feedback also generate emergence, which means the system as a whole has properties that do not exist if components are analyzed individually. While feedback effects create path dependency and stability, interactions also bring unpredictability. Small actions can have large effects while large actions have small effects (non-linear change), and actions may have unintended consequences.

Complex systems are often described as organic and contrasted with mechanical, complicated systems. A mechanical, engineered product may have many parts, but the parts interact in predictable ways - you can pull a machine apart, put it back together, and expect it to work in the same way. In contrast, a complex system cannot be taken apart and put back together piece-by-piece. Complex systems are more like ecosystems, in that the whole emerges through interactions and those interactions can be unpredictable and affected by contingencies.

This juxtaposition reflects the view that the natural and social sciences work from two base paradigms. ${ }^{58}$ One is based on Newtonian physics and it sees a world defined by stability, equilibriums, rationality, full knowledge and linearity-like a machine. The other is based on biology and it sees systems defined by evolution, perpetual change, and non-linear dynamics-like an ecosystem. In the social sciences, the former approach is exemplified by neoclassical economics and the latter by complexity economics. One starts from an assumption of stability and rationality and then makes exceptions to account for more ambiguous and messy realities. The other starts from an assumption of constant evolution and then looks for emergent patterns of temporary order that arise in the system.

The turn toward complexity theory in the social sciences divides opinion. For some scholars, it represents a paradigm shift with huge potential, while for others it adds little to wellestablished literatures on institutionalism or incrementalism. ${ }^{59}$ The machine/ecosystem division also attracts criticism. After all, international regimes are neither mechanical like clocks, nor natural like rainforests. Instead, they consist of a "set of diverse actors who dynamically interact with one another awash in a sea of feedbacks." 60 We discuss three reasons for

\footnotetext{
57 This definition is adapted from Oatley since his conceptualization of a complex system is tailored to international economic law and governance. Oatley, supra note 6.

58 Arthur, supra note 56.

${ }^{59}$ For explanations of why the use of complexity theory in international relations is controversial, see Paul Cairney, Complexity Theory in Political Science and Public Policy, 10 Pol. Stud. Rev. 346 (2012); Seva Gunitsky, Complexity and Theories of Change in International Politics, 5 INT'L THEORY 35 (2013).

${ }^{60}$ Miller \& PAGE, supra note 7 , at 7.
} 
skepticism about the applicability of complexity theory to international regimes, before proposing metrics to think about the relative complexity of different regimes.

The first reason for skepticism about complexity theory is confusion about what it includes and excludes, making it seem diffuse and ambiguous. Some theorists quip that part of complexity theory's wide appeal stems from complexity meaning different things to different people. ${ }^{61}$ While we note loose popular usage (for instance, widespread agreement that the U.S. tax system is too complex without reference to measures of tax code complexity), the scholarly literature does not share this indeterminacy; scholars by and large agree on the properties that define complex systems given above. ${ }^{62}$ In the Section below we bring the definition of a complex system to life by showing how participants at UNCITRAL describe the investment treaty system and how their words fit with defining traits of complex systems.

The second reason for skepticism about complexity theory in the social sciences is that it lacks appreciation for the nuances of particular contexts and how institutional or social landscapes are shaped by their histories. Some uses of complexity theory, notably in economics, have downplayed institutional and social context, hewing closely to complexity theory's origins in biological sciences. Downplaying context is not an intrinsic feature of complexity theory, however, and doing so here would be inappropriate for the richly institutionalized setting we observe at UNCITRAL and inconsistent with our para-ethnographic approach. Officials do not start with a blank slate. ${ }^{63}$ Graham Room, a complexity scholar of public policy, elaborates:

No policy is made on a tabula rasa: any policy is an intervention in a tangled web of institutions that have developed incrementally over extended periods of time and that give each policy context its own specificity. This history shapes the constraints and the opportunities within which policy interventions can then unfold. Policy terrains and policy effects are path dependent. ${ }^{64}$

The officials we observe at UNCITRAL are both constrained and enabled by what happened previously. This is what complexity theorists recognize when they observe that actors seeking change must find the "evolutionary potential in the present" rather than taking "an engineered approach rooted in an idealized future that may never come about." 65 If actors start from the present, it means they start with all the structures and constraints and nuances that exist from previous interactions. This perspective has much in common with other theories that emphasize

${ }^{61}$ Cairney, supra note 59 , at 352.

62 J.B. Ruhl \& Daniel Martin Katz, Measuring, Monitoring, and Managing Legal Complexity, 101 IowA L. REV. 191, 204-05 (2015) (identifying three defining properties that define complex systems: feedback, emergence, and self-organized, often path-dependent, structures). See also J.B. Ruhl, General Design Principles for Resilience and Adaptive Capacity in Legal Systems - with Applications to Climate Change Adaptation, 89 N.C. L. REV. 1373 (2011).

${ }^{63}$ On the imagery of a blank slate in international affairs, see Paul Pierson, The Path to European Integration: A Historical Institutionalist Analysis, 29 Comp. POL. STUd. 123, 146-47 (1996).

${ }^{64}$ Graham Room, Complexity, Institutions, and Public Policy: Agile Decision-Making in a Turbulent WORLD 7 (2011).

${ }^{65}$ Sonja Blignaut, Organizing Principles: The Spirit of Cynefin, in Cynefin: Weaving Sense-Making Into the Fabric OF Our World 63, 75 (Dave Snowden (\& Friends) eds., 2020). 
history and gradual institutional change. ${ }^{66}$ There are shared intellectual origins and parallel ideas about institutional evolution and strategies that actors use to change institutions over time. ${ }^{67}$

The third reason for skepticism about complexity theory in the social sciences is that it sometimes appears to present a deterministic argument with no scope for agency. As Paul Cairney explains: "If the complex system is predominantly the causal factor then we lose sight of the role that policy makers play; there may be a tendency to treat the system as a rule-bound structure that leaves minimal room for the role of agency." 68 Although some applications of complexity theory assume that the vision of agents is limited to their immediate local surroundings, that assumption is not appropriate here.

If our aim is to understand how sophisticated officials interpret, adapt to, and influence their decision-making environment, then more interpretive accounts of complexity theory are needed. ${ }^{69}$ Officials are not merely shuffling along pre-set paths, they are "agile path creators, able to explore distant hills and valleys, rather than moving myopically along merely local contours." 70 The agency of sophisticated actors is central to this Article: in Part III, we introduce the concept of complex designers to put a spotlight on these actors and how they seek to achieve their goals when they see themselves operating in a complex system. ${ }^{71}$

The insights that complexity theory can offer become increasingly relevant as systems grow more complex. All international regimes can be seen as complex adaptive systems yet, as Oran Young argues, the need for flexible and adaptable designs grows stronger as the environments in which these designs are expected to work grow more turbulent and unpredictable. ${ }^{72}$ To would-be designers, some complex systems are more stable and simpler to shape than others. It is helpful to think of complex systems as occupying varying places in the middle of a spectrum that runs from predictable and stable systems on one end to unpredictable and chaotic systems on the far end. ${ }^{73}$

${ }^{66}$ See Orion Lewis \& Sven Steinmo, How Institutions Evolve: Evolutionary Theory and Institutional Change, 44 POLITY 314 (2012) (pointing to parallels between institutionalism and evolutionary theory); RoOM, supra note 64, at 9-11 (calling for greater integration of institutionalism and complexity theory).

${ }^{67}$ For instance, Herbert Simon's work is cited as an inspiration by later generations of complexity theorists and institutionalist theorists, while Paul Pierson's landmark historical institutionalist work on path dependence draw heavily on complexity economist Brian Arthur. Paul Pierson, Politics in Time: History, Institutions, and Social Analysis 17-27 (2004). Generally on gradual institutional change, see John L. Campbell, Institutional Change and Globalization (2004); International Politics and Institutions in Time (Orfeo Fioretos ed., 2017); Beyond Continuity: Institutional Change in Advanced Political Economies (Wolfgang Streeck \& Kathleen Thelen eds., 2005); Kathleen Thelen, How Institutions Evolve: The Political Economy of Skills in Germany, Britain, the United States, and Japan (2004).

${ }^{68}$ Cairney, supra note 59 , at 352.

${ }^{69} \mathrm{Id}$. at 353.

${ }^{70}$ Room, supra note 64, at 8 (building on the work of Colin Crouch to describe actors as agile path creators and aiming "to develop models of agile action on complex terrains that can inform a new policy analytics").

${ }^{71}$ Our approach to this task and methods used are in line with Cairney and Room. Cairney, supra note 59, at 354 (suggesting "the best hope for complexity research is to develop such 'tool-kits' in cooperation with policy makers, since that interaction can produce new ideas and ways of thinking") and Room, supra note 64, at 5 (asking "what analytical tools . . . can be made available to policy-makers for the purpose of monitoring and steering these processes of transformation?").

${ }^{72}$ Young, supra note 6, at 176 (observing that in stable, predictable environments "institutional rigidity need not present a problem" but that "such arrangements are ill equipped to thrive or even survive, in volatile settings" that feature various types of change).

73 David J. Snowden \& Mary E. Boone, A Leader's Framework for Decision Making, Harv. Bus. Rev. (Nov. 2007), at https://hbr.org/2007/11/a-leaders-framework-for-decision-making. 
What makes an existing system more complex or less complex to would-be designers? There are no standard metrics to measure or compare the complexity of legal or governance systems. ${ }^{74}$ Yet would-be designers seem to operate with a practical sense that some contexts are more complex than others, so what shapes those perceptions? We articulate six characteristics that shape would-be designers' perceptions of complexity: ${ }^{75}$

1. Number, diversity, and connections of agents. How many agents and how many different types of agents are involved? How connected are they?

2. Number, diversity, and connections of formal structures. How many formal structures are there and how diverse are they? How connected are they?

3. Number, diversity, and connections of informal practices. How many informal practices exist and how variable are they? How connected are they?

4. Degree of dynamism of the issue area. How fast changing is the issue area? How often do new challenges or new information emerge?

5. Degree to which power is distributed. How widely is power distributed among wouldbe designers; who needs to agree?

6. Degree to which preferences diverge. How different are the visions of would-be designers for the future of this issue area; what do they want?

In general, an existing system feels more complex to would-be designers as each of these characteristics increase. If new information emerges frequently and would-be designers expect fast change, as in climate governance for instance, it increases perceived complexity. If there are many informal practices and they are highly variable in their operation, it increases perceived complexity. The patterns of connection in a governance system also shape perceived complexity; in general global governance is more complex as network structures grow denser, more modular, or more hierarchical. ${ }^{76} \mathrm{We}$ return to relative complexity in the conclusion as we assess the extent to which the emergent design approach we see at UNCITRAL is also visible in other contexts.

\section{B. The Investment Treaty System as a Complex Adaptive System}

Listening to participants at UNCITRAL, we are struck by how often their language echoes descriptions of complex adaptive systems. To describe the internal logic of how UNCITRAL participants see the investment treaty system, here we detail three ways in which they describe a system that is complex and full of adaptive actors. We observe negotiators treating the investment treaty system as a system (as thousands of treaties, actors, and other components that interconnect). We observe them treating the system as complex (that is, believing the interconnections give rise to unpredictability, feedback loops, and emergent patterns). And

\footnotetext{
${ }^{74}$ Ruhl \& Katz, supra note 62, at 238.

75 These characteristics draw on themes highlighted as useful for measuring complexity by Ruhl \& Katz, supra note 62, at 212-16 (agents and agent sets; formal architecture; network architecture; and information storage and computation) and characteristics that make an environment turbulent highlighted by Young, supra note 6, at 15 (attributes of the problem; political continuity; economic stability; technological innovations; emergence of new actors; shifting paradigms; state changes in biophysical systems; exogenous shocks).

${ }^{76}$ Rakhyun E. Kim, Is Global Governance Fragmented, Polycentric, or Complex? The State of the Art of the Network Approach, 22 InT'L STUD. ReV. 903, 917 (2020).
} 
we observe them treating the system as adaptive (because actors shape structures to suit their preferences and are also shaped by those structures, resulting in co-evolutionary dynamics).

First, negotiators treat the investment treaty system as a system. The system is made up of thousands of investment agreements with similar, though not always identical, provisions, which are interpreted and applied by hundreds of arbitral tribunals without a formal doctrine of precedent or system of appellate review. It includes multiple international organizations, including UNCITRAL, the United Nations Conference on Trade and Development (UNCTAD), and the Organisation for Economic Co-operation and Development (OECD), which serve the field in distinct yet overlapping ways. Cases are administered by different institutions, including the International Centre for Settlement of Investment Disputes (ICSID) and the Permanent Court of Arbitration (PCA), under various sets of procedural rules. Negotiators believe that interventions in one part of the system may affect other parts.

Negotiators see themselves operating within an existing system and view their interventions as occurring against this background. As one negotiator put it:

We are not starting from zero. There are over 3000 existing international investment agreements. There have been over 1000 ISDS cases. There are a range of well-established existing institutions like ICSID, the PCA, UNCTAD, the OECD, and, of course, UNCITRAL. There is a wealth of existing experience in practice that can be drawn on and harnessed from modern investment treaties. Accordingly . .., our approach . . . should reflect the fact that we're not painting on a blank canvas, but rather on one that is already full of color. ${ }^{77}$

Although states usually negotiate investment treaties on a bilateral or regional basis, they view UNCITRAL as a forum where they come together multilaterally to consider what systemic problems exist and which systemic responses might be appropriate. UNCITRAL was selected in large part because of its "genuinely multilateral" nature-all member states of the United Nations General Assembly are members of UNCITRAL. ${ }^{78}$ It is the hub for international commercial law reform within the United Nations system, and has long been active in arbitration, promulgating influential arbitration rules and model laws, including most recently, the Mauritius Convention. As a multilateral instrument designed to update numerous existing agreements, this Convention exemplified a systemic approach.

Negotiators at UNCITRAL frequently emphasize the need for systemic and multilateral approaches. According to one: "[I]t [is] important and necessary to adopt a multilateral approach, necessarily a systemic approach. In other words we need to look at these issues not just from a bilateral point of view but also from a multilateral one. This is the reason why we're here." 79 According to another: "[I]n order to identify the problems related to ISDS system, a holistic approach should be taken. These problems are systemic in nature.

\footnotetext{
77 Australia, Transcript of Audio from UNCITRAL Working Group III (ISDS Reform), 39th Sess., Oct. 9, 2020, 15:00-17:00.

${ }^{78}$ Communications on file with authors.

${ }^{79}$ Argentina, Transcript of Audio from UNCITRAL Working Group III (ISDS Reform), 34th Sess., Nov. 29, 2017, 9:30-12:30.
} 
So they should be neither considered in isolation nor solved by minor adjustments to the current system." 80

Taking a systemic approach does not mean that all negotiators think that a single, uniform approach will resolve their problems. Instead, different negotiators have sought different "leverage points" in the system where they could intervene in small ways with the aim of achieving larger, systemic effects. ${ }^{81}$ For example, the European Union and its member states view the selection of adjudicators as a key leverage point in changing the system's underlying paradigm. They argue that, by shifting from arbitral appointments by the disputing parties to permanent appointments by the treaty parties, the "paradigm" for understanding appointments would change from a commercial arbitration model to a public international law one. ${ }^{82}$ Other states, academics, and civil society groups at UNCITRAL see reframing the system's underlying object and purpose to align with sustainable development as a high leverage point. ${ }^{83}$ These approaches accord with arguments that the two highest-impact leverage points for intervening in systems are reframing a system's underlying paradigm and rethinking its goals. ${ }^{84}$

Second, negotiators treat the investment treaty system as a complex system. The investment treaty system is complex in a structural sense because it is multi-levelled and polycentric. ${ }^{85}$ But this is not the essence of what makes a system complex within the meaning of complexity theory. The essential feature of a complex system is that it functions like an ecosystem in the sense that its parts are interconnected and interdependent, meaning you cannot understand the whole from examining the parts in isolation. Instead, the way that they interact is essential to understanding the whole and the outcomes of these interactions can be unpredictable. Interactions can give rise to emergent patterns of temporary order, as well as unintended consequences where an intervention aimed at one problem can unintentionally cause another problem. Complex systems emerge and evolve, they do not proceed like clockwork.

Negotiators, like complexity theorists, often focus on interactions. The reform of ISDS is complex because "different concerns are intertwined and are systemic," notes one submission. ${ }^{86}$ Because reforms are interconnected, another noted, any individual reforms adopted

\footnotetext{
${ }^{80}$ Poland, Transcript of Audio from UNCITRAL Working Group III (ISDS Reform), 34th Sess., Nov. 29, 2017, 9:30-12:30.

${ }^{81}$ Donella Meadows, Leverage Points: Places to Intervene in a System, Donella Meadows Archives, at http:// donellameadows.org/archives/leverage-points-places-to-intervene-in-a-system; JoHN H. Holland, HidDEN Order: How Adaptation Builds Complexity 5, 40, 93-94 (1995).

${ }^{82}$ European Union, Transcript of Audio from UNCITRAL Working Group III (ISDS Reform), 40th Sess., Feb. 8, 2021, 15:00-17:00.

${ }^{83}$ Submission from the Government of South Africa: Possible Reform of Investor-State Dispute Settlement (ISDS), UNCITRAL Working Group III (Investor-State Dispute Settlement Reform), 38th Sess., Oct. 2019, UN Doc. A/CN.9/WG.III/WP.176, at https:/undocs.org/en/A/CN.9/WG.III/WP.176; Matthew C. Porterfield, Lise Johnson \& Brooke Skartvedt Guven, Reforming the International Investment Regime Through a Framework Convention on Investment and Sustainable Development, UNCITRAL (Oct. 6, 2020), available at https://uncitral.un.org/sites/uncitral.un.org/files/media-documents/uncitral/en/a_framework_convention_on_investment.pdf.

${ }^{84}$ Meadows, supra note 81.

85 The term "polycentric" or many-centered, is drawn from Elinor Ostrom's conceptualization of international climate governance, which she saw as a complex system with multiple centers of dynamism. Elinor Ostrom, Beyond Markets and States: Polycentric Governance of Complex Economic Systems, 100 Am. Econ. Rev. 641, 641-72 (2010). On polycentricity, see Governing Climate Change: Polycentricity in Action? (Andrew Jordan, Dave Huitema, Harro van Asselt \& Johanna Forster eds., 2018).

${ }^{86}$ Submission from the European Union and Its Member States: Possible Reform of Investor-State Dispute Settlement (ISDS), UNCITRAL Working Group III (Investor-State Dispute Settlement Reform), 37th Sess.,
} 
would not be an "isolated outcome" but would serve "a greater purpose," as "the sum of all of them is, in itself, a holistic reform." ${ }^{87}$ In addition to systemic effects, negotiators are mindful about unintended consequences. Reform is "complex," warned another, so "States must be mindful that any new solutions could also bring new problems into the equation." 88

Some negotiators at UNCITRAL seek to work with interconnections. For instance, the European Union advocates for an appellate mechanism to reduce incorrectness and inconsistency, and to decrease the cost and duration of proceedings. ${ }^{89} \mathrm{~A}$ single reform is intended to have multiple effects. Interconnections, however, also give rise to unpredictability and unintended consequences. Negotiators do not know which reforms will be adopted or whether they will have their intended effect; nor can they predict which cases will be brought or how tribunals will interpret treaty provisions. As one negotiator observed, "[T]he people who ... developed the [investment treaty] system in the 1960s and 1970s would not have been able to foretell the evolution of the system." ${ }^{90}$ Awareness of the potential for unintended consequences instills a sense of humility and caution in negotiators.

While negotiators cannot fully predict the system's evolution, they are able to discern emergent patterns. For instance, although the investment treaty system is not multilateral, treaty terms adopted by powerful states are more likely to be adopted by others than those formulated by less powerful states. ${ }^{91}$ The system lacks a doctrine of precedent, yet certain awards develop quasi-precedential status. ${ }^{92}$ And in the absence of permanent adjudicators, a small handful of arbitrators receive most of the appointments and have played an outsized role in driving the field's emerging jurisprudence. ${ }^{93}$ These self-organizing patterns emerge

Apr. 2019, UN Doc. A/CN.9/WG.III/WP.159/Add.1, at https://undocs.org/A/CN.9/WG.III/WP.159/Add.1; see also Submission from the Government of Thailand: Possible Reform of Investor-State Dispute Settlement (ISDS), UNCITRAL Working Group III (Investor-State Dispute Settlement Reform), 37th Sess., Apr. 2019, UN Doc. A/CN.9/WG.III/WP.162, at https://undocs.org/A/CN.9/WG.III/WP.162.

${ }^{87}$ Submission from the Government of Costa Rica: Possible Reform of Investor-State Dispute Settlement (ISDS), UNCITRAL Working Group III (Investor-State Dispute Settlement Reform), 38th Sess., Oct. 2019, UN Doc. A/CN.9/WG.III/WP.178, at https://undocs.org/A/CN.9/WG.III/WP.178.

${ }^{88}$ Submission from the Government of Thailand, supra note 86.

${ }^{89}$ Submission from the European Union and Its Member States, supra note 86, at 4 (observing before introducing an appellate mechanism that "the concern as regards the costs of the system is linked to the concern as regards the lack of predictability which is in turn linked to the concerns with the methods of arbitrator appointments which is in turn linked to the concerns with arbitrators' independence and impartiality").

${ }^{0}$ The Debate on ISDS Reform, Main Narratives and Tensions Moderated by Dr. Inga Martinkute, Vilnius University, YouTube (May 13, 2021), at https://www.youtube.com/watch?v=-6pRUzoIrdI (comment by Colin Brown at 39:00).

${ }^{91}$ Wolfgang Alschner \& Dmitriy Skougarevskiy, The New Gold Standard? Empirically Situating the TransPacific Partnership in the Investment Treaty University, 17 J. World Inv. \& Trade 339 (2016); Wolfgang Alschner, The Impact of Investment Arbitration on Investment Treaty Design: Myths Versus Reality, 42 YALE J. INT'L L. 1, 33 (2017) (observing that almost all innovations in treaty drafting in the period examined can be linked to one agreement: the NAFTA).

${ }^{9}$ Wolfgang Alschner, Ensuring Correctness or Promoting Consistency? Tracking Policy Priorities in Investment Arbitration Through Large-Scale Citation Analysis, in The Legitimacy of InVESTMENT Arbitration: EMPIRICAL Perspectives (Daniel Behn, Ole Kristian Fauchald \& Malcolm Langford eds., 2021); Damien Charlotin, The Place of Investment Awards and WTO Decisions in International Law: A Citation Analysis, 20 J. INT'L ECON. L. 279 (2017); Niccolò Ridi, The Shape and Structure of the "Usable Past": An Empirical Analysis of the Use of Precedent in International Adjudication, 10 J. InT'L DisP. SeTtLement 200 (2019).

93 Sergio Puig, Social Capital in the Arbitration Market, 25 Eur. J. InT'L L. 387 (2014); Malcolm Langford, Daniel Behn \& Runar Hilleren Lie, The Revolving Door in International Investment Arbitration, 20 J. INT'L ECON. L. 301 (2017). 
through the interaction of the system's constituent components despite the lack of centralized control. ${ }^{94}$ UNCITRAL negotiators debate how to shift some of these emergent patterns, like the unrepresentative nature of arbitral appointments.

Third, negotiators treat the investment treaty system not only as complex, but also as adaptive. Complex systems are adaptive when they include actors that develop preferences in response to structures and incentives created by the system and also shape those structures and incentives in ways that suit their preferences using their skills and knowledge. There is "a recursive loop" in which "aggregate outcomes form from individual behavior, and individual behavior, in turn, responds to these aggregate outcomes." 95 This coevolutionary dynamic is particularly important when dealing with human actors in what some scholars call complex adaptive social systems. ${ }^{96}$

UNCITRAL negotiators debate how to change the structures and incentives of the system to shift the identity, interests, and ideas of various actors within the system, including states, private actors like law firms or arbitrators, public actors like secretariats, and civil society groups. This suggests negotiators are conscious of the importance of agency. When investor-state arbitration was first added to investment treaties, no law firms specialized in investment arbitration, but the creation of these treaty rights spurred law firms to specialize and in turn to help reshape the system by bringing cases that extended its application. ${ }^{97}$ The negotiators know that if they change the system's structures, for instance by regulating third party funding, they could affect the identities, ideas, and interests of actors within the system. They also know that sophisticated actors might seek to negate or work around reforms they dislike.

The negotiators are also conscious of the adaptive nature of their own states. Contemporary negotiating positions are often shaped by decisions made in the past, including treaties signed or positions taken in past cases. While past precedents may constrain negotiators, they do not fully determine contemporary positions: there can be scope for new thinking and change even if negotiators need to navigate carefully between various constraints. The negotiators are also conscious of how the ground frequently shifts underneath their feet: they face new cases, new adjudicatory decisions, other treaty negotiations, the rise of new political parties to power, and shifting geopolitical dynamics. They look to each other-on the UNCITRAL floor and in the corridors - to see how others react to proposals, creating networked behavior that can permit changes of view to coalesce quickly or be stalled indefinitely.

\section{Complex Designers}

To foreground the agency of actors at UNCITRAL who see themselves operating in a complex system yet still seek to design or redesign it, we introduce the concept of complex designers.

\footnotetext{
94 Alec Stone Sweet \& Florian Grisel, The Evolution of International Arbitration: Judicialization, Governance, Legitimacy (2017).

${ }^{95}$ W. Brian Arthur, Foundations of Complexity Economics, 3 Nature Reviews Physics 136 (2021) 136.

96 On complex adaptive social systems, see Miller \& PAGE, supra note 7, at xvii. On complex socioecological systems, see Fikret Berkes, Carl Folke \& Johan Colding, Linking Social and Ecological Systems: Management Practices and Social Mechanisms for Building Resilience (2000); see also Navigating Social-Ecological Systems: Building Resilience for Complexity and Change (Fikret Berkes, Johan Colding \& Carl Folke eds., 2003).

97 Yves Dezalay \& Bryant G. Garth, Dealing in Virtue: International Commercial Arbitration and the Construction of a Transnational Legal Order (2015); St John, supra note 42.
} 
Complex designers include representatives of states as well as actors like NGOs seeking reforms to strengthen environmental protection and industry groups working to protect the interests of investors. ${ }^{98}$ Some actors, like states, are both designers and users. ${ }^{99}$ Complex designers at UNCITRAL are many and varied: they have different identities as well as divergent ideas and interests concerning what the system is and should be. Instead of parsing which actors count as designers or considering the goals and strategies of any particular complex designer, this Article adopts a systems-level approach. Whatever their individual objectives and strategies, as a collective the participants at UNCITRAL are operating as complex designers. How should we conceptualize their approach?

To explain the role of complex designers, we pick up on some of the metaphors used by participants at UNCITRAL and characterize the designers as landscape architects. Landscape architects work with the existing land but can also reshape the land and build or demolish structures. They work toward an overall or emerging vision yet know that their vision will take a long time to come to fruition and may need to be altered in response to changing circumstances. Landscape architects design both to withstand and to work with their environment. Even after their design is implemented, they will need to manage and care for their gardens, planting and pruning each year. In this way, landscape architects engage in both initial design and ongoing management.

We use this metaphor to explain the role of complex designers for three reasons. First, metaphors are an effective method for formulating new concepts and explaining them. ${ }^{100}$ No metaphor is perfect and all metaphors provide ways of seeing and not seeing, but they play a meaningful part in cognitive processes by helping us to understand something new through comparisons with something familiar. ${ }^{101}$

Second, metaphors are a key device used by participants in the UNCITRAL process when attempting to introduce new concepts or persuade other participants to adopt particular approaches. Indeed, the frequent and colorful use of metaphors and analogies has been remarked upon by participants. ${ }^{102}$ Whether the process can deal with both structural and non-structural reforms becomes a question of whether participants can "walk and chew gum at the same time." The two types of reform have been characterized as "multiple

98 "Everyone designs who devises courses of action aimed at changing existing situations into preferred ones," explains economist Herbert Simon in his work on the "science of design." Herbert A. Simon, The SCIenCes of THE ARTIFICIAL 111 (1996).

${ }^{99}$ Anthea Roberts \& Taylor St John, UNCITRAL and ISDS Reform: In Sickness and in Health, EJIL:TALK! (Oct. 23, 2019), at https://www.ejiltalk.org/uncitral-and-isds-reform-in-sickness-and-in-health (noting that some states seem to cast themselves as patients suffering ailments within the system, while other states (often more powerful ones) envision their role as doctors capable of administering treatments for those ailments).

${ }^{100}$ On the importance of metaphors in shaping thinking, see George LaKoff \& MarK Johnson, Metaphors We Live By (2003 [1980]); Gareth Morgan, Images of Organization (2021 [2006]); Paul H. Thibodeau \& Lera Boroditsky, Metaphors We Think with: The Role of Metaphor in Reasoning, 6 PLOS ONE (2011). On the importance of metaphors in discovering new relationships and conveying them to wider audiences, see Howard Gardner, Frames of Mind: The Theory of Multiple Intelligences 306-07 (2011).

${ }^{101}$ On the use of metaphors in international law, see Harlan Grant Cohen, Metaphors of International Law (2020), at https://papers.ssrn.com/sol3/papers.cfm?abstract_id=3659901.

${ }^{102}$ See, e.g., Chair, Transcript of Audio from UNCITRAL Working Group III (ISDS Reform), 40th Sess., Feb. 10, 2021, 11:00-13:00 ("one of the things that I enjoy most about this particular Working Group is the colorful idioms and analogies that are often employed in explaining positions"); Sierra Leone, Transcript of Audio from UNCITRAL Working Group III (ISDS Reform), 37th Sess., Apr. 4, 2019, 15:00-18:00 (reflecting on enjoying "the literary beauty of metaphors" used in the negotiations). 
lanes" on a "single highway toward reform utopia." 103 There are metaphors about chasing rabbits and constructing with building blocks, to name just a few. ${ }^{104}$

Third, although the landscape architect metaphor has not been used on the UNCITRAL floor, we take inspiration from two of its components that have been invoked repeatedly: architecture and gardening. Complex designers are architects in the sense that they seek to design new structures with users in mind and gardeners in the sense that they try to seed and harvest different reform options in light of changing environmental conditions.

To move from the metaphorical to the analytical, we identify specific procedural and substantive lessons that can be derived from each metaphor. Procedurally, architects remind us of the centrality of episodic design and redesign, while substantively they aim at designing structures with adaptive users in mind. Substantively, gardeners focus on the exigency of environmental fit, while procedurally they remind us of the need for continuous calibration through adaptive management. Most complex designers combine elements of both architecture and gardening, but the balance between the two can shift over time or by context.

\section{A. Architects}

The notion of architecture is prominent when it comes to envisaging structures for bringing the reforms together and the role of negotiators in designing those structures.

In presentations, the UNCITRAL Secretariat uses architectural images of a house and floor plans to explain how different design options relate to each other (Figures 1 and 2). Different dispute settlement options represent the first and second floors of this house, under a roof of state control. Support for the parties and alternative dispute settlement are indicated by side buildings proximate to the main house but outside it. Different procedural reforms stand for different rooms on a single floor that states can enter or not. The Secretariat outlines "possible architecture" for bringing the reforms together, noting that the "actual architecture" will depend on which reforms are pursued. ${ }^{105}$

Other participants employ architectural language to explain the current system's design flaws (e.g., problems arise from its fragmented "architecture") ${ }^{106}$ and their aspirations for reforms (e.g., "We would like the architecture to be flexible"107 and "[O]pen architecture

${ }^{103}$ Australia, Transcript of Audio from UNCITRAL Working Group III (ISDS Reform), 37th Sess., Apr. 2, 2019, 15:00-18:00; United States, Transcript of Audio from UNCITRAL Working Group III (ISDS Reform), 37th Sess., Apr. 3, 2019, 10:00-13:00; Australia, Transcript of Audio from UNCITRAL Working Group III (ISDS Reform), 37th Sess., Apr. 3, 2019, 10:00-13:00.

${ }^{104}$ Russian Federation, Transcript of Audio from UNCITRAL Working Group III (ISDS Reform), 38th Sess., Oct. 14, 2019, 14:00-17:00 ("if you chase after two rabbits, you won't catch either of the two rabbits"); Ukraine, Transcript of Audio from UNCITRAL Working Group III (ISDS Reform), 38th Sess., Oct. 17, 2019, 14:0017:00 ("we'll also invite the Secretariat to . . chase and capture as many rabbits as possible"); United States, Transcript of Audio from UNCITRAL Working Group III (ISDS Reform), 37th Sess., Apr. 3, 2019, 10:0013:00 ("The proposals from Thailand and Costa Rica also employ the concept of building blocks as a way to view the solutions that the working group can pursue. And we think this is a helpful metaphor for thinking about our way forward.").

${ }^{105}$ See Multilateral Instrument on ISDS Reform: Possible Reform of Investor-State Dispute Settlement (ISDS), UNCITRAL Working Group III (Investor-State Dispute Settlement Reform) 39th Sess., Mar.-Apr. 2020, UN Doc. A/CN.9/WG.III/WP.194, at https://undocs.org/en/A/CN.9/WG.III/WP.194.

${ }^{106}$ Switzerland, Transcript of Audio from UNCITRAL Working Group III (ISDS Reform), 40th Sess., Feb. 9, 2021, 15:00-17:00.

107 Brazil, Transcript of Audio from UNCITRAL Working Group III (ISDS Reform), 40th Sess., Feb. 8, 2021, 15:00-17:00. 


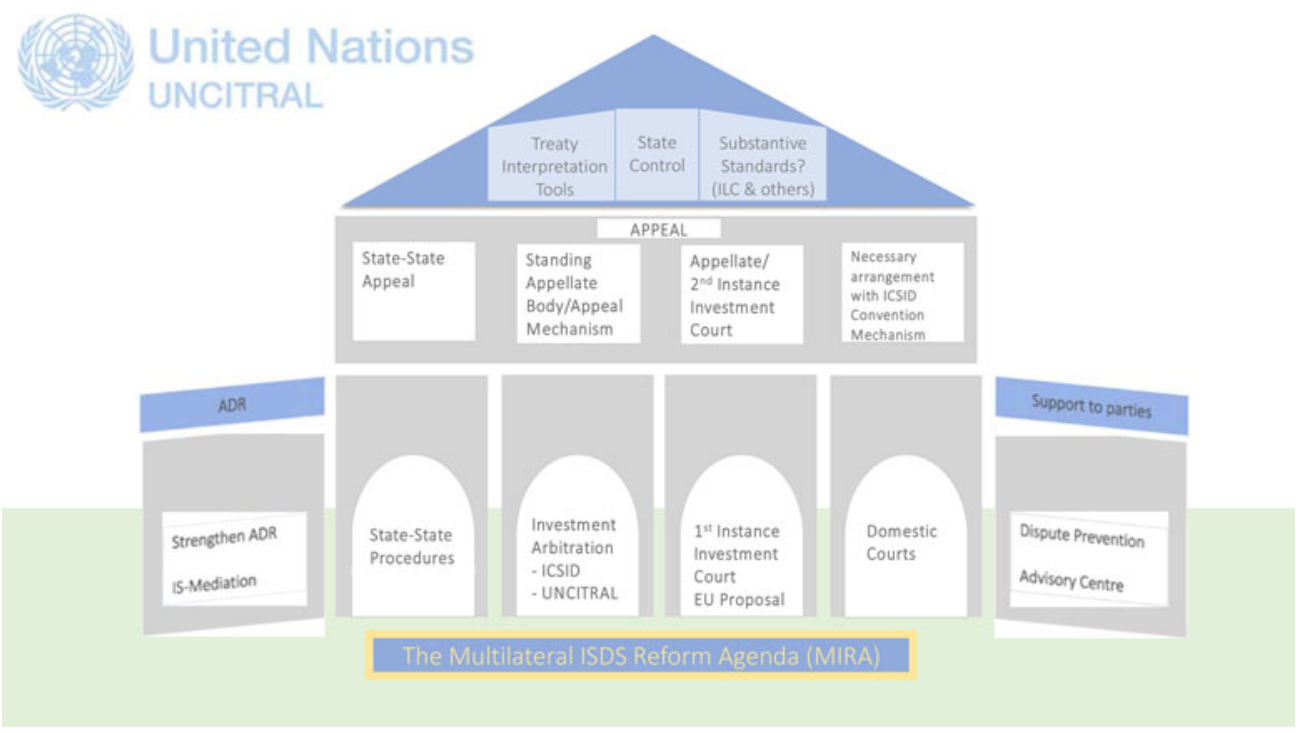

FIGURE 1. Visualization of architectural design on a potential multilateral instrument

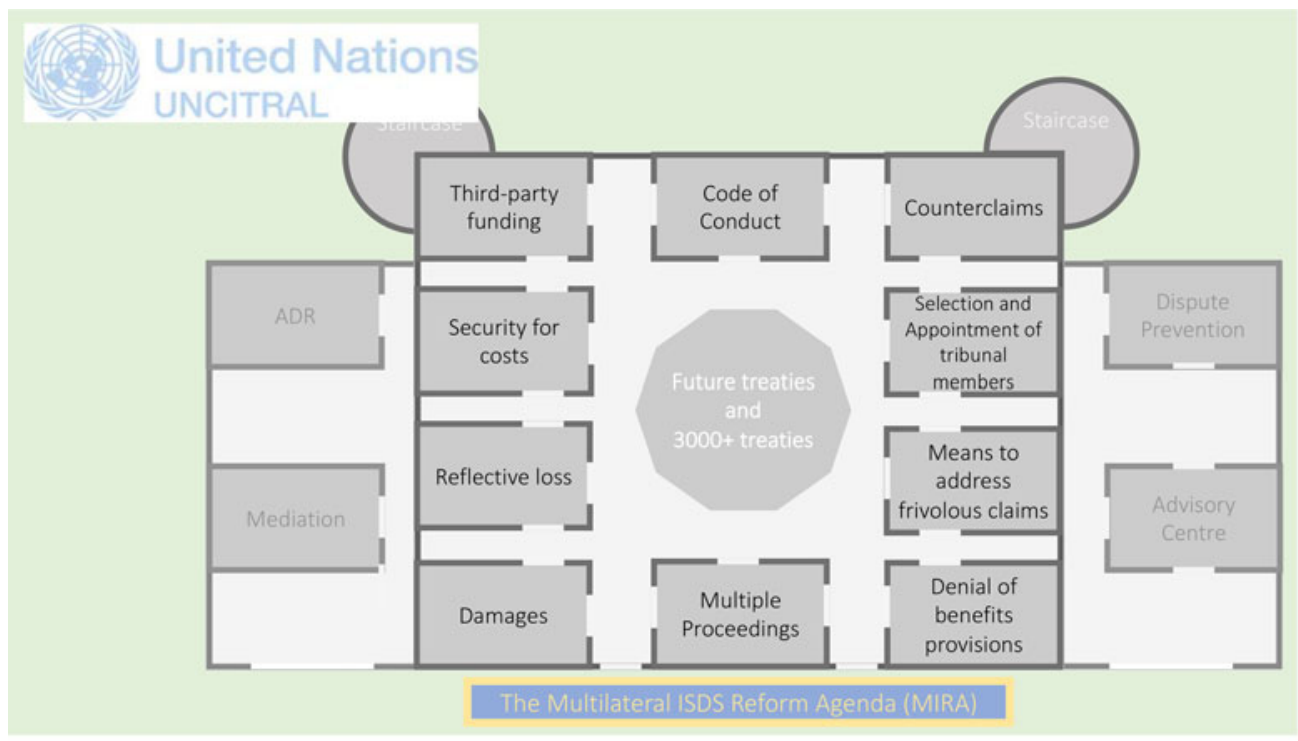

FIGURE 2. Visualization of a floor plan of potential procedural reform options

of the standing mechanism could be a way of providing for such flexibility" ${ }^{108}$ ). In discussing the multilateral instrument, the Chair explains the "need to understand some of the architecture of where we might be headed." ${ }^{109}$ He has also drawn on architectural metaphors in seeking to move participants to the drawing board:

${ }^{108}$ Submission from the European Union and Its Member States, supra note 86, at 9.

${ }^{109}$ Chair, Transcript of Audio from UNCITRAL Working Group III (ISDS Reform), 40th Sess. resumed, May 4, 2021, 13:00-15:00. 
[W]e heard it expressed that being asked to work on the selection of adjudicators in the context of a standing mechanism was like being asked to dive headfirst into a pool that was not deep enough and where we would hit our head.

As colorful, and as frankly a little bleak as that analogy is, I also think that it is not quite right-because at the stage of the work where we are at, I would suggest the pool has yet to be even designed let alone constructed and filled with water.

Instead, I would suggest that where we are at is that we are standing still on solid ground, hearing about where a pool might go, and what its design might be, but some delegations are already saying that it will be too shallow. And then when the builder and architect suggests otherwise, and offers to draw it out, to design it, and to show the specifications, there seem to be those who are saying we should simply say no, we don't want to see that work, instead we wish to simply continue in our assumption that we were right about the pool's depth without even looking at the plans. ${ }^{110}$

\section{Engaging in Episodic Design and Redesign}

The idea of architecture serves as a useful way of thinking about the role of complex designers who design and redesign structures and institutions. Negotiators representing states engage in the process of design when they enter into a new treaty or establish a new institution. Likewise, negotiators at UNCITRAL are engaging in a process of redesign by considering how the investment treaty system should be reformed in light of concerns about how it is operating. Such episodic processes of design and redesign tend to be conscious and visible. They involve meetings of states and mandates. Plans are drawn up and institutions are created, modified, and decommissioned.

Architects work intensively during the design phase but are usually not involved once the building is constructed, unless to design extensions or renovations later. Since it is costly and difficult to erect buildings, architects try to anticipate what will be needed in the future, which may signal a flexible layout with rooms that can be used for different purposes or wiring that allows new rooms to be easily added. Similarly, since institutional infrastructure tends to be time-consuming and expensive to set up, and opportunities to redesign it to be rare, complex designers at UNCITRAL aspire to build flexibility and adaptability into their designs. We observe this aim in calls for flexible instruments enabling different parties to accept different obligations, and an adaptable framework that would allow modular additions, like new protocols, to be added in the future.

At UNCITRAL, some negotiators are considering how they could design structures to be put to new purposes over time. For instance, former European Trade Commissioner Cecilia Malmström observed that any new institution would "need to be flexible in jurisdiction, and able to handle evolution in the content of treaties, for example if countries decide to extend them to cover investor obligations." 111 Or if a court of first instance or body of permanent

${ }^{110}$ Chair, Transcript of Audio from UNCITRAL Working Group III (ISDS Reform), 40th Sess., Feb. 10, 2021, 11:00-13:00.

${ }^{111}$ Cecilia Malmström, Eur. Comm'r for Trade, A Multilateral Investment Court: A Contribution to the Conversation About Reform of Investment Dispute Settlement, Speech Before Belgian Ministry of Foreign Affairs (Nov. 22, 2018), available at https://trade.ec.europa.eu/doclib/docs/2018/november/tradoc_157512.pdf. 
adjudicators is created, some wonder if it could be made available for investor-state and statestate claims and, if so, whether it could include both trade and investment disputes under free trade agreements. Like architects, today's negotiators can design structures that are adaptable and amenable to serving tomorrow's goals, even when they cannot know what those goals will be.

Negotiators are also like architects in that their choices are shaped by the particularities of a given site. As one UNCITRAL participant stated, "[T] opography does dictate what can be done." 112 Sometimes architects have to work with existing buildings or intrinsic features such as rocks and gradients. It can take imagination to envisage how unwanted structures or features could be repurposed or remodeled to achieve new ends. So, too, are negotiators often constrained by the structures and features already in place and forced to decide what to keep and what to discard, what to repurpose and what to remodel.

Although architects design for a specific site, the design process often involves creatively recombining features that have been developed and tested elsewhere. Innovation is frequently combinatorial rather than genuinely novel and new institutions often assemble a bricolage of features developed elsewhere. ${ }^{113}$ At UNCITRAL, we find complex designers drawing lessons from their experiences in bilateral and multilateral investment treaty negotiations, as well as from trade law, human rights law, and (to a lesser extent) environmental law. Like architects, one challenge these designers face is to consider new features systemically and in context, since features that work well separately or elsewhere might not work well together or in this context.

\section{Designing Structures with Adaptive Users in Mind}

Like architects, negotiators at UNCITRAL are tasked with designing structures while keeping adaptive users in mind. When designing buildings, architects must consider the identity, interests, and likely behavior of different users, and design experts often emphasize the importance of taking user-centered approaches. ${ }^{114}$ Like architects, we observe designers at UNCITRAL asking themselves questions such as: Which users and uses do we want to encourage or discourage? What are the interests of different potential users, and how are those users likely to respond to different structures and incentives?

We also observe designers at UNCITRAL asking as a prior set of questions: who should count as a "user" in the investment treaty system? Should cases be brought only by investors or also by states? Should NGOs be permitted to bring cases or participate as non-disputing parties? What about affected communities? Should third-party funders be allowed within the system? Through these sorts of decisions, complex designers craft structures that include or exclude, empower or disempower, different actors.

112 Communications on file with authors.

113 On bricolage as a means of institutional design, see Nikhil Kalyanpur \& Abraham Newman, Form Over Function in Finance: International Institutional Design by Bricolage, 24 REV. INT'L Pol. Econ. 363 (2017). On the role of institutional entrepreneurs who "cast around for elements of institutions that they could recombine in unusual ways at opportune moments in order to produce change," see Colin Crouch, CAPITALIST Diversity and Change: Recombinant Governance and Institutional Entrepreneurs 3, 18-20, 87-88 (2007). On bricolage in organizations and societies, see Karl E. Weick, Improvisation as a Mindset for Organizational Analysis, 9 ORG. SCI. 5 (1998).

114 Tim Brown, Change by Design: How Design Thinking Transforms Organizations and Inspires INNOVATION 235-36 (2009). 
Various interest groups remind the UNCITRAL designers not to forget users. For instance, a representative of EFILA (European Federation for Investment Law and Arbitration) cautioned that "many architects forget the users" and reminded the system's "architects" that it was "important to keep the users in mind in this whole process." 115 To EFILA, investors represent the key users. But to other interest groups, more actors should be recognized as key users, including developing states lacking adequate resources to defend claims or NGOs and community groups desirous of standing to bring and intervene in cases. ${ }^{116}$

The users of the investment treaty system are not limited to disputing parties; they also include adjudicators. Lack of diversity in appointments is a frequent concern raised at UNCITRAL, prompting calls for greater gender and regional balance. ${ }^{17}$ Some actors note the advisability of diversity and inclusivity in general terms; ${ }^{118}$ others point to the role they play in ensuring that decision making draws on the insights of people with varied ideas and lived experiences. ${ }^{119}$ "The decisionmaking process is likely to be perceived as fairer if the decisionmakers are more diverse, thus enhancing the legitimacy of a mechanism," according to one negotiator, and representation by a range of nationalities increases the likelihood of choosing an adjudicator with some local knowledge. ${ }^{120}$

${ }^{115}$ Malcolm Langford, Multilateral Instrument on ISDS reform - Webinar \#3: UNCITRAL Secretariat \& ISDS Academic Forum, YouTube (May 14, 2020), at https://www.youtube.com/watch?v=NI_SESUsNwE\&feature= youtu.be.

${ }^{116}$ Submission to UNCITRAL Working Group III on ISDS Reform, Contributed by Columbia Center on Sustainable Investment (CCSI), International Institute for Environment and Development (IIED), and International Institute for Sustainable Development (IISD), Third Party Rights in Investor-State Dispute Settlement: Options for Reform, UNCITRAL (July 15, 2019), available at https://uncitral.un.org/sites/uncitral.un.org/files/media-documents/ uncitral/en/wgiii_reformoptions_0.pdf.

117 See, e.g., Kenya, Transcript of Audio from UNCITRAL Working Group III (ISDS Reform), 38th Sess., Jan. 23, 2020, 14:00-17:00 ("It will be critical that we balance geographical and gender representation, as well as representation of the various legal systems that are enforced. These issues have been at the very heart of, of concern for developing countries, not as a superficial requirement, but an essence of inclusivity in the processes that adjudicate on investments that are paid for by public funds. As long as developing countries continue to be distanced from the epicenter of decisions, the result and systems will suffer a crisis of legitimacy."); Indonesia, Transcript of Audio from UNCITRAL Working Group III (ISDS Reform), 38th Sess., Jan. 23, 2020, 14:00-17:00 ("Diversity should be seriously considered in the selection and appointment process of arbitrators or adjudicators, especially on gender balance, geographical distribution, and different legal systems. . . . [I]t will be logical that a balance needs to be struck between arbitrators from developing and developed countries.").

${ }^{118}$ European Union, Transcript of Audio from UNCITRAL Working Group III (ISDS Reform), 40th Sess., Feb. 8, 2021, 11:00-13:00 ("Diversity requirements, linguistic requirements, and knowledge of different legal systems should be built into any convention or statute establishing such a permanent mechanism.”); Chile Transcript of Audio from UNCITRAL Working Group III (ISDS Reform), 38th Sess., Jan. 23, 2020, 9:0012:30 (appointments should be "based on gender diversity, nationality, and language, and candidates should understand political, cultural, economic realities").

${ }^{119}$ On the importance of cognitive diversity — different ways of thinking — in reaching good judgments in complex situations, as well as the link between cognitive and other types of diversity, such as race, gender, and socioeconomic class, see Scott E. Page, The Difference: How the Power of Diversity Creates Better Groups, Firms, Schools, and Societies (2007); Lu Hong \& Scott E. Page, Groups of Diverse Problem Solvers Can Outperform Groups of High-Ability Problem Solvers, 46 Proc. NaT'L Acad. ScI. 16385 (2004); Scott E. Page, Where Diversity Comes from and Why It Matters?, 44 Eur. J. Soc. Psych. 267 (2014).

${ }^{120}$ South Africa, Transcript of Audio from UNCITRAL Working Group III (ISDS Reform), 40th Sess., Feb. 9, 2021, 11:00-13:00. See also Tunisia, Transcript of Audio from UNCITRAL Working Group III (ISDS Reform), 38th Sess., Jan. 22, 2020, 14:00-17:00 ("We should also take into account equitable representation, and also a balanced distribution of legal cultures and doctrines ... [because standards like] fair and equitable treatment can mean something different depending on the legal system or culture in a country."). 
Designs both shape and are shaped by their users in a coevolutionary manner. As commentators on architecture note, the ability of architects to shape the behaviors of users can be hard to discern ("Good design is obvious. Great design is transparent." ${ }^{121}$ ), but there are limits to their power ("People ignore design that ignores people."122). The structures that architects design can influence the identity and behavior of users, but users may also ignore or work around structures they find problematic. "The paradox of impact is that while design shapes the world in profound ways, it is also being shaped by the world," which means that architects function as "critical mediators," not complete controllers. ${ }^{123}$

Negotiators at UNCITRAL know they are designing for adaptive actors who navigate structures to pursue their own ideas and interests. If negotiators change the system's structures, they can affect the identities, ideas, and interests of actors within the system. For example, they could require adjudicators to have experience in public international law or international economic law but not international commercial arbitration. ${ }^{124}$ Yet they understand that actors might seek to work around reforms they dislike. For example, interest groups at UNCITRAL suggest investors may bypass ISDS if there is no party appointment, perhaps by signing contracts that permit international commercial arbitration. ${ }^{125}$

Negotiators are keenly aware of the dual role of states as architects and users, and the need to design with users in mind. ${ }^{126}$ These conditions play out in debates over appointments; some actors argue that permitting treaty parties to appoint all the adjudicators would "lead to a mechanism biased in favor of states." 127 Others respond that when states appoint permanent adjudicators rather than ad hoc arbitrators, they do so as a treaty party, rather than as a disputing party. As one negotiator put it, in ad hoc appointments, disputing parties typically

${ }^{121}$ Joe Sparano, QUOTES ON DeSIGN, at https://quotesondesign.com/joe-sparano.

122 Frank Chimero, QuOTES ON DeSIGN, https://quotesondesign.com/frank-chimero.

123 Tania Allen, Solving Critical Design Problems: Theory and Practice 201 (2019) (“Design as a process necessarily interfaces with many other systems to shape and redefine the world and our human experience within it. Designers and design in general is, however, uniquely situated to be critical mediators between the various entities, forces, and agendas that are constantly at work in developing the future.").

${ }^{124}$ Submission from the Government of China: Possible Reform of Investor-State Dispute Settlement (ISDS), UNCITRAL Working Group III (Investor-State Dispute Settlement Reform) 38th Sess., Oct. 2019, UN Doc. A/CN.9/WG.III/WP.177, at http://undocs.org/en/A/CN.9/WG.III/WP.177.

125 Submission to UNCITRAL Working Group III on ISDS Reform, Contributed by European Federation for Investment Law and Arbitration, Ensuring Equitable Access to all Stakeholders: Critical Suggestions for the MIC, UNCITRAL (July 15, 2019), available at https://uncitral.un.org/sites/uncitral.un.org/files/media-documents/ uncitral/en/wgiii_efila.pdf ("UNCITRAL Working Group III must address the risk that private parties will not see the MIC as a viable forum for enforcing the treaty protections granted to them by States."); Submission to UNCITRAL Working Group III on ISDS Reform, Contributed by Corporate Counsel International Arbitration Group and United States Council for International Business, Comments: Appointment of Arbitrators, Appellate Mechanism, and Enforcement, UNCITRAL (Dec. 4, 2020), available at https://uncitral.un.org/sites/uncitral.un. org/files/media-documents/uncitral/en/120420_cciag_and_uscib_comments_on_december_15_uncitral_papers.pdf (observing that a proposed permanent court "will not be perceived as fair by investors, and they will alter their investment decisions accordingly").

${ }^{126}$ Anthea Roberts, Power and Persuasion in Investment Treaty Interpretation: The Dual Role of States, 104 AJIL 179 (2010).

${ }^{127}$ Bahrain, Transcript of Audio from UNCITRAL Working Group III (ISDS Reform), 40th Sess., Feb. 8, 2021, 11:00-13:00. See also EFILA, Transcript of Audio from UNCITRAL Working Group III (ISDS Reform), 40th Sess., Feb. 9, 2021, 15:00-17:00 (agreeing with Bahrain); USCIB, Transcript of Audio from UNCITRAL Working Group III (ISDS Reform), 40th Sess., Feb. 9, 2021, 11:00-13:00; CCIAG, Transcript of Audio from UNCITRAL Working Group III (ISDS Reform), 40th Sess., Feb. 9, 2021, 11:00-13:00. 
appoint someone who is likely to "defend their interests," but "the viewpoint of [states] when making appointments changes radically from ad hoc to permanent system."128

By locating decision-making power in different places (e.g., with the treaty parties instead of the disputing parties) and at different times (e.g., before a case has arisen instead or after one has been filed), UNCITRAL designers may try to influence the identity of appointees and the ideas and incentives that shape the appointments. One submission describes the process as follows:

When appointing adjudicators to the standing mechanism, the contracting parties would be expected to appoint objective adjudicators, rather than ones that are perceived to lean too heavily in favour of investors or states, because they are expected to internalize not only their defensive interests, as potential respondents in investment disputes, but also their offensive interests, i.e. the necessity to ensure an adequate level of protection to their investors. They will therefore take a longer term perspective. ${ }^{129}$

\section{B. Gardeners}

Negotiators at UNCITRAL also frequently invoke the imagery of gardening with respect to the process. Negotiators publicly discuss whether they should work on reforms that would permit an "early harvest," or are ripe for picking; they ask whether the Group should focus on "low hanging fruit" or whether such fruit is already being picked elsewhere. ${ }^{130}$ In private, some characterize planting seeds for reform and cultivating support as engaging in "patient gardening" that leads to feelings of success when some of the "gardening gradually [starts] blooming" or begins "bearing fruit." They also recognize the need to intervene when the "Garden [has gone] a bit awry." 131

\section{Designing with Environmental Fit in Mind}

For a landscape architect or gardener, understanding the environment is the starting point for design, and working with or against the environment is a continuing process. "Effective gardening requires the right setting: fertile soil, good light, water. It requires a strong view as to what should and should not be grown. . . . It requires a hard-headed willingness to weed what does not belong." 132 As one UNCITRAL participant states: "Part of the difference in approaches between structural (architect) and procedural (gardener) reform is that the former

${ }^{128}$ European Union, Transcript of Audio from UNCITRAL Working Group III (ISDS Reform), 40th Sess., Feb. 8, 2021, 15:00-17:00.

${ }^{129}$ Submission from the European Union and its Member States, supra note 86, at 6.

${ }^{130}$ United States, Transcript of Audio from UNCITRAL Working Group III (ISDS Reform), 38th Sess., Oct. 16, 2019, 14:00-17:00 (observing a code of conduct "is a strong candidate for an early harvest as a product"); Costa Rica, Transcript of Audio from UNCITRAL Working Group III (ISDS Reform), 38th Sess., Oct. 14, 2019, 10:00-12:30 ("achieving early harvest results"); Australia, Transcript of Audio from UNCITRAL Working Group III (ISDS Reform), 38th Sess., Oct. 17, 2019, 14:00-17:00 (suggesting "phased entry into force to allow for early harvest"); Singapore, Transcript of Audio from UNCITRAL Working Group III (ISDS Reform), 39th Sess., Oct. 9, 2020, 15:00-17:00 ("the harvesting of these lower hanging fruits").

${ }^{131}$ Communications on file with authors.

132 Eric Liu \& Nick Hanauer, The Gardens of Democracy: A New American Story of Citizenship, the ECONOMY, AND THE ROle OF GOVERNMENT 1 (2011). 
seems to want to design to withstand the elements and the landscapers/gardeners are developing with the elements in mind." 133

Landscape success is often judged by how well a design suits its wider environment. Gardeners know that different plants are more likely to survive and thrive in different environments. Similarly, different institutions fit different environments. ${ }^{134}$ An institution, like a plant, may grow more durable over time through continued support; for instance, the Group of Seven was created as a temporary experiment but generated unanticipated positive feedback, which led it to endure. ${ }^{135}$ An institution can also generate negative feedback or worsening fit with its wider environment over time, which may engender perceptions of ineffectiveness or illegitimacy. ${ }^{136}$

Perceptions of a legitimacy crisis in ISDS and public discontent clearly motivate the negotiators at UNCITRAL. One asked, "How do we maintain the legitimacy of ISDS?" before answering:

I think perceptions matter and . . . are key to this idea of social license and if I could just briefly quote from a Chief Justice of the English court: "Justice should not only be done but it should manifestly and undoubtedly be seen to be done again." From Australia's perspective I think it's important that both real and perceived problems should be considered. At the end of the day we are all accountable to the public and we need to counter public perceptions to be relevant. ${ }^{137}$

Perceptions of ISDS within the wider environment matter for those engaging in reforms because they affect the system's legitimacy and functioning. ${ }^{138}$

Even though landscape architects pay close attention to their environment, a wide range of visions is still possible: rigid Versailles-like gardens could be imposed or thoughtful, yet minimal alterations could be made, like Nanzen-in garden in Kyoto. The extent to which designers work with existing materials or transform the landscape is a design choice. Some complex designers at UNCITRAL view architecture as preceding gardening. For instance, one negotiator reasons:

[T]he architect is creating the structures, and must design intelligently, whilst the gardener comes along later (maybe just very slightly later) and has to make sure that the living body which has been created (populated by humans, with all their failings) grows up strong. I've understood for some time that creating the architecture is only the first step,

133 Communications on file with authors.

${ }^{134}$ Barbara Koremenos, Charles Lipson \& Duncan Snidal, The Rational Design of International Institutions, 55 INT'L ORG. 761, 762 (2001) (observing that "design differences are not random . . . they are the result of rational, purposive interactions among states and other international actors to solve specific problems”). See also JOSEPH Jupille, Walter Mattli \& Duncan Snidal, Institutional Choice and Global Commerce 9 (2013).

135 Orfeo Fioretos, Minilateralism and Informality in International Monetary Cooperation, 26 REV. INT'L POL. ECON. 1136 (2019)

${ }^{136}$ YounG, supra note 6, at 171-78 (describing the effectiveness of four governance regimes by evaluating the changing fit between these four regimes and their wider environments).

137 Australia, Transcript of Audio from UNCITRAL Working Group III (ISDS Reform), 34th Sess., Nov. 29, 2017, 9:30-12:30

${ }^{138}$ Mauritius, Transcript of Audio from UNCITRAL Working Group III (ISDS Reform), 34th Sess., Nov. 29, 2017, 9:30-12:30 (speaks at 1:56 in the recording); South Africa, Transcript of Audio from UNCITRAL Working Group III (ISDS Reform), 34th Sess., Nov. 29, 2017, 9:30-12:30. 
the next step would be getting the people in place who can make sure that there is life in the house, and that is the tending and planting which a gardener would do. You need both, but not at the same time. ${ }^{139}$

Others see a greater commingling of the two functions in the role of the landscaper. As another participant explains, "I wonder if 'landscaper' isn't a broader but more accurate [metaphor than] gardener, since there seems to be a suggestion that the gardeners don't have a larger vision, when I think they do." 140 The vision for a landscape like Central Park in New York is not implemented once and then left alone, it is created and recreated through many small interventions over time.

Environments can be dynamic, even volatile, and institutions that work well in a stable environment may prove rigid and lacking in resilience in the face of change, such as shifts in the balance of power. ${ }^{141}$ The Appellate Body of the World Trade Organization (WTO) is an example that looms large in the minds of UNCITRAL negotiators. Long considered the "jewel in the crown" of the trading system, the Appellate Body proved vulnerable when the United States refused to appoint new members. ${ }^{142}$ The Appellate Body fit its environment well in the 1990s but proved vulnerable when the political environment changed.

To keep dispute settlement operating, some states at the WTO turned to a little-used option of Article 25 arbitration, invoking and repurposing it as a temporary replacement for appeals. ${ }^{143}$ Vulnerability can accompany some highly centralized designs that have single points of failure or chokepoints, whereas maintaining more diversity and redundancy can help institutions adapt to changing conditions.

\section{Engaging in Adaptive Management}

Unlike architects, gardeners have not completed their work once an initial design has been implemented. After seeds are planted, gardeners tend their plots, observing young shoots and well-established plants alike and calibrating conditions to ensure that they flourish. The process is more like continuous calibration through adaptive management than episodic design and redesign.

A gardener's interventions are often corrective; observing an increase in rainfall this month, a gardener turns off the irrigation line. Part of the job is to anticipate future scenarios and

${ }^{139}$ Communications on file with authors.

${ }^{140}$ Communications on file with authors.

${ }^{141}$ YounG, supra note 6, at 177 (emphasizing that an institution's fit with its wider environment is crucial for effectiveness and observing that the key question for regimes operating in volatile environments is "whether regimes are resilient in the sense that they have the capacity to make significant changes to cope with external stresses in a manner that leaves their fundamental character unchanged")

${ }^{142}$ World Trade Organization Press Release, WTO Disputes Reach 400 Mark (Nov. 6, 2009), at https://www. wto.org/english/news_e/pres09_e/pr578_e.htm; "Unprecedented Challenges" Confront Appellate Body, Chair Warns, WTO NEWs (June 22, 2018), at https://www.wto.org/english/news_e/news18_e/ab_22jun18_e.htm; Manfred Elsig, Mark Pollack \& Gregory Shaffer, Trump Is Fighting an Open War on Trade. His Stealth War on Trade May Be Even More Important, WASH. PosT (Sept. 27, 2017), at https://www.washingtonpost.com/news/ monkey-cage/wp/2017/09/27/trump-is-fighting-an-open-war-on-trade-his-stealth-war-on-trade-may-be-evenmore-important.

${ }^{143}$ Statement on a Mechanism for Developing, Documenting and Sharing Practices and Procedures in the Conduct of WTO Disputes, WTO Doc. No. JOB/DSB/1/Add.12 (Apr. 30, 2020), available at https://trade. ec.europa.eu/doclib/docs/2020/april/tradoc_158731.pdf. 
design accordingly, yet gardeners also know that their work faces threats they cannot predict. They cannot plan everything ahead of time like architects do; gardeners must be flexible and respond to changing conditions as they go. ${ }^{144}$ Thus, despite the UNCITRAL Working Group's agreement on a list of reforms to consider, the chair has emphasized that the schedule "remains open to the identification of new concerns" citing damages as a potential example. "We will always have to remain adaptable and flexible. None of us have a crystal ball."145

When invoking gardening as a metaphor for governing, Eric Liu and Nick Hanauer observe: “Great gardeners would never simply 'let nature take its course.' They take responsibility for their gardens." Gardening presupposes "instability and unpredictability; and thus expects a continuous need for seeding, feeding, and weeding ever-changing systems." Gardeners know that great gardens are "sustainable only with continuous investment and renewal." To garden is to "tend." 146 Other commentators point out that "the 'gardening' skills of senior leadership should be to tend, prune, and harvest ideas." 147 For example, the European Union has been seeking to plant the seeds for a new multilateral investment court while also pruning (i.e., terminating) its intra-EU investment treaties.

Complex designers at UNCITRAL recognize the need to seed reforms and then observe them closely, with monitoring processes and tools to intervene if corrective measures are required. Regular meetings of the treaty parties in an interpretive commission serve as one such monitoring mechanism, and interpretive statements are one such tool. ${ }^{148}$ Of course, treaty parties can only intervene or make interpretations if they are able to reach an agreement on how to act in accordance with the requirements of the treaty, which may often prove impossible in practice due to a lack of capacity or differences in interests among the treaty parties. More generally, UNCITRAL has started to function as a common hub where states discuss the system as a whole. ${ }^{149}$

Being in a position to make regular adjustments, whether big or small, is important. Sometimes monitoring may lead to a major redesign, but often it results in tweaks, such as redirecting or expanding a budget or fine-tuning the rules. Dynamic environments require adaptive management and such monitoring and intervention processes are likely to outlive

${ }^{144}$ As the writer George Martin explains of the two jobs: "The architects plan everything ahead of time. . . They have the whole thing designed and blueprinted out before they even nail the first board up. The gardeners dig a hole, drop in a seed and water it. ... [A]s the plant comes up and they water it, [but] they don't know how many branches it's going to have, they find out as it grows." George R.R. Martin, George R.R. Martin-Quotes-Quotable Quote, GoodReADS, at https://www.goodreads.com/quotes/749309-i-think-there-are-two-types-of-writers-thearchitects\#: : text=The\%20architects\%20plan\%20everything\%20ahead,plumbing\%20there's\%20going\% 20to\%20be. See also Joshua Cooper Ramo, The Age of the Unthinkable: Why the New World Disorder Constantly Surprises Us and What We Can Do About It (2009) (“Seeing the world as a ceaselessly complex and adaptive system . . . involves changing the role I imagine for ourselves . . . from architects of a system I can control . . . to gardeners living in a shifting ecosystem that is mostly out of our control.").

${ }^{145}$ Chair, Transcript of Audio from UNCITRAL Working Group III (ISDS Reform), Resumed 40th Sess., May 4, 2021, 13:00-15:00.

${ }^{146}$ LiU \& HANAUER, supra note 132 , at $1,6,11,6$.

${ }^{147}$ Brown, supra note 114 , at 80.

148 See Interpretation of Investment Treaties by Treaty Parties: Possible Reform of Investor-State Dispute Settlement (ISDS), UNCITRAL Working Group III (Investor-State Dispute Settlement Reform), 39th Sess., Mar.-Apr. 2020, UN Doc. A/CN.9/WG.III/WP.191, at http://undocs.org/en/A/CN.9/WG.III/WP.191.

${ }^{149}$ Anthea Roberts \& Taylor St John, UNCITRAL and ISDS Reform: Visualising a Flexible Framework, EJIL: TALK! (Oct. 24, 2019), at https://www.ejiltalk.org/uncitral-and-isds-reform-visualising-a-flexible-framework. 
the initial UNCITRAL process. As one negotiator explains of a potential multilateral instrument:

[A]ny such instrument will have to be sufficiently flexible as to be able to build in additional rules that may be necessary in the future. An example of this is the issue of thirdparty funding. It's an important issue today and has been an important issue over the last few years. But if you looked at the debates around ISDS 10 years ago, or 15 years ago, the question of the party funding was not present. We cannot predict what our successors in 10 or 15 years may view as issues, which may also need to be addressed. So this flexibility for future rules has to be built in. ${ }^{150}$

\begin{tabular}{lll}
\hline & \multicolumn{1}{c}{ Procedural } & \multicolumn{1}{c}{ Substantive } \\
\hline Architects & Focus on episodic design and redesign & Designing institutions in light of adaptive users \\
Gardeners & Focus on adaptive management & Designing institutions in light of the environment \\
\hline
\end{tabular}

\section{EMERgent Design}

Although it is too early to tell which reforms (if any) will ultimately be adopted at UNCITRAL, the approach being taken by the Working Group so far and the key design principles that underlie this approach are already clear. In this Part, we develop three principles we see at UNCITRAL: flexible structures, balanced content, and adaptive management processes. We refer to them as emergent design principles and note that similar notions of emergent design are appearing across a range of areas. ${ }^{151}$ These principles also resemble adaptive management principles and ideas from polycentric, experimentalist, and networked governance-academic literatures that we consider part of the wider turn to complexity theory. ${ }^{152}$

${ }^{150}$ European Union, Transcript of Audio from UNCITRAL Working Group III (ISDS Reform), 39th Sess., Oct. 9, 2020, 15:00-17:00.

${ }^{151}$ Ann Pendleton-Jullian \& John Seely Brown, Design Unbound: Designing for Emergence in a White Water World, chs. 9-11 (2018) (who advocate for an architectural philosophy of "designing for emergence"); Zoltán I. Búzás \& Erin R. Graham, Emergent Flexibility in Institutional Development: How International Rules Really Change, 64 INT'L STUD. Q. 821 (2020) (who suggest designing for “emergent flexibility” in institutions).

152 The notion of "adaptive governance" or "adaptive management" is most frequently applied in areas dealing with socioecological systems. See Carl Folke, Thomas Hahn, Per Olsson \& Jon Norberg, Adaptive Governance of Social-Ecological Systems, 30 Ann. Rev. EnvTl. Resources 441, 441-73 (2005); Timothy Karpouzoglou, Art Dewulf \& Julian Clark, Advancing Adaptive Governance of Social-Ecological Systems Through Theoretical Multiplicity, 57 Envtl. SCI. \& POL'y 1, 1-9 (2016); Lyndal Hasselman, Adaptive Management; Adaptive CoManagement; Adaptive Governance: What's the Difference?, 24 Australasian J. EnvTl. MgMt. 31, 31-36 (207). These emergent design principles also find resonance with theories of polycentric governance. Elinor Ostrom, Institutions and the Environment, 28 Econ. AfF. 24, 24-31 (2008); Elinor Ostrom, A Polycentric Approach for Coping with Climate Change (Policy Research Working Paper 5095, 2009), available at http://documents1.worldbank.org/curated/en/480171468315567893/pdf/WPS5095.pdf. They also find resonance in theories of experimentalist governance; Gráinne De Búrca, Robert O. Keohane \& Charles Sabel, Global Experimentalist Governance, 44 BRIT. J. Pol. SCI. 477, 477-86 (2014); Charles F. Sabel \& Jonathan Zeitlin, Learning from Difference: The New Architecture of Experimentalist Governance in the EU, 14 EuR. L.J. 271, 271-327 (2008); Jonathan Zeitlin, Extending Experimentalist Governance? The European Union and Transnational Regulation (2015); and networked governance; Networked Politics: Agency, Power, and Governance (Miles Kahler ed., 2009). They additionally find resonance in theories of network governance; Kim, supra note 76; Rakhyun E. Kim, The Emergent Network Structure of the Multilateral Environment Agreement System, 23 GLOB. ENVTL. CHANGE 980, 980-91 (2013); as well as scholarship combining resilience thinking with institutionalist theory; Duit \& Galaz, supra note 19; Andreas Duit, Resilience Thinking: Lessons for Public Administration, 94 
Like many scholars, we turn to complexity theory for analytical reasons, because it is useful for describing and conceptualizing what we observe at UNCITRAL. It helps demonstrate that there is a coherence and logic underlying the negotiators' approach. We recognize, however, that outlining an approach in detail and connecting theory to practice has normative implications. Making a normative argument is not our main purpose here, and we do not make a normative argument for or against any specific reform to the investment treaty system. But we do see value in emergent design approaches. In that sense we make a broader argument: when negotiators perceive themselves to be acting in a dynamic complex adaptive system, we expect that they will often adopt emergent design approaches, and we believe these approaches may provide effective ways to achieve their aims.

Why are negotiators at UNCITRAL turning to an emergent design approach? It is instructive to return to the six characteristics that shape would-be designers' perceptions of complexity sketched above, particularly dynamism, power, and preferences. New information about the investment treaty system is emerging ever faster and some negotiators at UNCITRAL feel they may be working just ahead of a new controversial case or large damages award; there is dynamism and a sense of urgency. Power is distributed widely. No actor has the power to insist upon its approach being accepted as the only approach. And state approaches differ sharply. China, the European Union, and the United States all have different visions of the way forward, for example. The preferences of other states, and even their views on the reform mandate being too extensive or not extensive enough, diverge. These characteristics lead negotiators to perceive relatively high levels of complexity in the negotiation.

Additionally, the UNCITRAL negotiators see themselves as working within an existing complex adaptive system, as noted above. None of the proposed reforms could or should be "developed in a vacuum," explained one negotiator, because designers must contend with "over three decades of decisions and state practice" and "almost 3000 different agreements" extant. ${ }^{153}$ Even when advocating for far-reaching reform, delegates proclaim that they "do not want to throw the baby out with the bathwater." 154 Other negotiators note that "there is no need to reinvent the wheel" to emphasize that the Working Group should draw on work done by other international organizations or language in recent treaties. ${ }^{155}$

Pub. Admin. 364, 364-80 (2016); Martin Sjöstedt, Resilience Revisited: Taking Institutional Theory Seriously, 20 Ecology \& Soc'y 23, 23-31 (2015); Martin Sjöstedt, Governing for Sustainability: How Research on Large and Complex Systems Can Inform Governance and Institutional Theory, 29 ENVTL. POL'y \& Governance 293, 293-302 (2019).

${ }^{153}$ United States, Transcript of Audio from UNCITRAL Working Group III (ISDS Reform), 40th Sess., Feb. 8, 2021, 15:00-17:00. This sentiment echoes complexity theorists who liken actors seeking to reform complex systems to passengers on an aircraft who must both fly the plane and redesign it in flight; they cannot stop the plane and go back to the drawing board. John Sterman, Business Dynamics: Systems Thinking and Modeling For a COMplex WORLd 4 (2000).

${ }^{154}$ Mauritius, Transcript of Audio from UNCITRAL Working Group III (ISDS Reform), 37th Sess., Apr. 3, 2019, 10:00-13:00; see also ASIL, Transcript of Audio from UNCITRAL Working Group III (ISDS Reform), 37th Sess., Apr. 2, 2019, 15:00-18:00 (observing, "It's eminently sensible not to throw the baby out with the bath").

155 Thailand, Transcript of Audio from UNCITRAL Working Group III (ISDS Reform), 38th Sess., Oct. 16, 2019, 9:30-12:30; Australia, Transcript of Audio from UNCITRAL Working Group III (ISDS Reform), 38th Sess., Oct. 17, 2019, 9:30-12:30 (encouraging the Working Group to "build on some of the work that's been done in modern agreements without necessarily having to reinvent the wheel in that regard"); see also Singapore Transcript of Audio from UNCITRAL Working Group III (ISDS Reform), 38th Sess., Oct. 16, 2019, 9:30-12:30 (observing "we do not think the Secretariat needs to reinvent the wheel by drafting a code of conduct from scratch”). 
UNCITRAL negotiators' perceptions that they are operating in an existing system, amid complexity, has been central to their decision to adopt an evolutionary and experimental approach to reform. We know from discussions that some negotiators adopted this approach reluctantly, after realizing that more direct paths to their aims were not available to them. Some negotiators may wish that they were starting with a blank slate or that their state was powerful enough to make its preferred approach the only blueprint for ISDS reform. But since they do not start with a blank slate and since no one actor is powerful enough to mandate a single design, negotiators opted to work toward their varying reform aims over time, through evolution and experimentation.

Evolutionary modes of change take place when several slightly different versions of a rule or procedure appear, followed by the selection and replication of some of these versions and the withering of others. These three steps — variation, selection, and replication — are the core of evolutionary change. ${ }^{156}$ Evolutionary change has already occurred in the investment treaty system; for instance, states created different variations of the same treaty provisions, and then some of these variations were widely replicated while others declined in prominence. ${ }^{157}$ The difference at UNCITRAL is that negotiators can collectively monitor variations and make selection a conscious process. Evolutionary processes can be achieved faster and more efficiently by institutions than in the natural world. ${ }^{158}$

In taking an evolutionary approach, experimentation is key-something which is permitted by the flexible, opt-in structure envisaged for the multilateral instrument being discussed at UNCITRAL. Pioneers of applied complexity, like Dave Snowden and Yaneer Bar-Yam, argue in favor of adopting multiple, preferably simultaneous, small-scale experiments coupled with monitoring to see what works and what does not, while watching for unintended consequences. Instead of seeking a single "fail-safe" design, Snowden advocates trying multiple "safe-to-fail" experiments to see how the complex system responds to different probes by amplifying successes and dampening failures. ${ }^{159}$ Bar-Yam likewise advocates "enlightened evolutionary engineering," which involves experimenting with incremental adaptations followed by monitoring. ${ }^{160}$

Although UNCITRAL was chosen as the forum for these reforms for other reasons, its working methods and traditional decision-making procedures lend themselves to

\footnotetext{
${ }^{156}$ Lewis \& Steinmo, supra note 66. But see CAMPBELL supra note 67, at 174 (defining evolutionary change more widely, by contrasting evolutionary change to revolutionary change ("Revolutionary change involves simultaneous change across most, if not all, dimensions of an institution over a given period of time; evolutionary change consists of change in only a few of these dimensions; and stability consists of the absence of change in most, if not all, of these dimensions. So, for any episode of change, change may be located on a continuum, which ranges from stability on one end, through increasing degrees of evolutionary change in the middle, and through increasing degrees of revolutionary change on the other end.")).

${ }^{157}$ Alschner \& Skougarevskiy, supra note 91, at 583-84 (observing that several states largely replicated British investment treaties, including Barbados, India, Israel, and Ghana).

${ }^{158}$ Lewis \& Steinmo, supra note 66, at 335.

${ }^{159}$ Snowden \& Boone, supra note 73. Experiments that fail may turn out to be unexpectedly costly, however, since the stakes in the investment treaty system can be high. For instance, a treaty or procedural innovation may create more opportunities for claims or claimants might use the Most Favored Nation clause to make a small experiment much wider in applicability than anticipated by states. Even if they are aiming for low-cost experiments, negotiators at UNCITRAL face risks, especially from unforeseen interconnections in the system.

${ }^{160}$ Yaneer Bar-Yam, Making Things Work: Solving Complex Problems in a Complex World (2004).
} 
experimentation and evolutionary approaches. ${ }^{161}$ Block-Lieb and Halliday argue that incrementalism is a defining trait of UNCITRAL's working methods. ${ }^{162}$ After surveying its lawmaking in three areas, they conclude that "a dynamic model of incrementalism was employed by UNCITRAL and . . this policy of incrementalism allowed it simultaneously to expand its ambitions, build legitimacy, and increase its access to other tangible and intangible resources." 163 UNCITRAL's incrementalism has included building on prior efforts by other international organizations, digging into an area more deeply over progressive rounds, and widening the substantive boundaries of the topics it seeks to embrace in successive rounds. ${ }^{164}$

Working iteratively and looking for small interventions that might have outsize systemic effects, rather than striving for one big reform now, might actually serve the negotiators' aims better over time. According to Roger Martin, a professor of management who uses complexity approaches:

The performance of a complex adaptive system is not improved dramatically with the pulling of a single lever .... What's more, in a complex adaptive system, the unintended consequences of a singular big, bold move can often undo the hoped-for-benefits of that one move and even make the situation worse .... [W] ith a complex adaptive system, not even the smartest mind can know with reasonable certainty - if any certainty at allwhat the best direction is. In this context, big is definitely not better. So, [designers] should start small, ending up with dramatic change at the end of many small steps. ${ }^{165}$

Is this what we see at UNCITRAL, that designers are starting small but will end up with dramatic change at the end of many small steps? Is this how they understand the purpose of evolutionary or incremental reforms?

Many in the investment law community assume that the purpose of incremental reforms is to sustain the existing system. Academics and civil society observers express concern that small-scale corrective actions may end up "locking in a broken system"166 _ a concern we return to in the conclusion. In our observation, an important group of states do see incremental changes as a way to introduce sustaining innovations into the existing system with an aim of stabilizing rather than transforming it.

It is also possible for incremental reforms to be transformative, however, and we observe some states aiming for this approach. Gradual revolution through incremental changes can be the most effective available path to more far-reaching, lasting transformation. Small changes can have big effects. If states were to eliminate the most-favored-nations clause, or apply it

${ }^{161}$ We examine the choice for UNCITRAL as the forum in Roberts \& St John, supra note 10.

162 BlOCK-LIEB \& HallidAY, supra note 21, at 80-91 (describing how UNCITRAL has deployed incrementalism in three forms), and more generally 50-91 (providing a detailed analysis of UNCITRAL's evolution as a law-making body and how it has "invented new legal technologies that offered greater flexibility to reform a broader range of laws, especially with the benefit of time and incremental progress").

163 Block-Lieb \& Halliday, supra note 21 , at 83.

${ }^{164} I d$. at $83-84$.

165 Roger Martin, When More Is Not Better: Overcoming America's Obsession with Economic EFFICIENCY 211-12 (2020).

${ }^{166}$ Lisa Sachs, Lise Johnson, Brooke Guven, Jesse Coleman \& Ladan Mehranvar, The UNCITRAL Working Group III Work Plan: Locking in a Broken System?, CCSI (May 4, 2021), at https://mailchi.mp/law/the-uncitral-working-group-iii-work-plan-locking-in-a-broken-system?e $=52229118 \mathrm{f} 4$. 
only to prospective treaties or substantive provisions, the dynamics of the investment treaty system would change significantly. ${ }^{167}$ So, too, if states were to endorse a different way of interpreting damages clauses. ${ }^{168}$

Changes that look minor individually may be transformative when viewed over time or in combination. ISDS provisions were added to investment treaties over several decades; each addition seemed small when viewed in isolation, but collectively they transformed the system. ${ }^{169}$ Reforms can also be incremental-in-step but wide-in-scope; political scientist Yuen Yuen Ang argues that a combination of gradual and broad changes may work best to produce transformative results, because incremental reforms in one area activate reforms in other areas, producing complementarities. ${ }^{170}$

Incremental or evolutionary processes can also generate momentum or set in motion new processes. Discussions at UNCITRAL may set in motion various processes that could lead to outcomes not currently on the agenda. At the international level, the UNCITRAL process may spur competitive reform dynamics among international organizations, increasing incentives for UNCTAD and the OECD to push forward substantive reforms. At the national level, the UNCITRAL process may lead to new inter-ministerial conversations, creating pressure for formal inter-ministerial processes to be created where they do not already exist.

At this point, it is too early to tell if the evolutionary approach adopted at UNCITRAL will lead to transformative outcomes or not. Negotiators themselves cannot fully predict the effects of individual changes, let alone how certain reforms might interact with other reforms or if current discussions might build momentum for broader reforms in the future. Expectations among participants about where this process might lead vary-an issue we return to in the conclusion.

Despite varying expectations about and evaluations of potential longer-term outcomes, actors seem to share an understanding of what is happening at UNCITRAL in the shorterterm. As a descriptive matter, states are creating tools through which they can monitor and manage the investment treaty system to shape its evolution and emergence. In the rest of this section, we explain how the UNCITRAL negotiators are pursuing this goal through creating flexible structures, pursuing balanced content, and establishing adaptive management processes. These principles form the essence of their emergent design approach.

\section{A. Flexible Structures}

The foundation of the UNCITRAL reform approach is a flexible structure that would enable individual states to choose which reforms they wish to accept and update their reform options and choices over time. Instead of developing a single "optimal" design, this flexible

\footnotetext{
${ }^{167}$ On how different approaches to the MFN clause could have systemic effects, see Simon Batifort \& J. Benton Heath, The New Debate on the Interpretation of MFN Clauses in Investment Treaties: Putting the Brakes on Multilateralization, 111 AJIL 873 (2018).

168 On how damages calculations could be reframed with systemic effects, see Emma Aisbett \& Jonathan Bonnitcha, A Pareto-Improving Compensation Rule for Investment Treaties, 24 J. InT'L Econ. L. 181 (2021); Jonathan Bonnitcha \& Emma Aisbett, Against Balancing: Revisiting the Use/Regulation Distinction to Reform Liability and Compensation Under Investment Treaties, 42 MicH. J. INT'L L. 231 (2021).

169 St John, supra note 42, at 183-210.

170 Yuen Yuen Ang, How China Escaped the Poverty Trap 74-77 (2017).
} 
approach is premised on the acceptance by states of continuing diversity in their approaches and adaptability of the instrument over time.

At UNCITRAL, negotiators regularly extol the virtues of a flexible reform structure that would permit diversity and enable choice. Negotiators have repeatedly emphasized that "there is no one-size-fits-all solution" 171 and that states should be given "maximum flexibility" to "choose and adopt the best solution based on their specific needs and interests."172 What is being contemplated, indicates another, is a "menu of different dispute settlement options, which states can choose to opt in[to] according to their appetites," and which would amount to a "sensible, flexible, and inclusive way to deal with the diversity and different permutations of reform." 173 The goal is to "build reform functionally and flexibly rather than in a one-size-fits-all structure." 174

For the negotiators at UNCITRAL, flexibility is fundamental: "flexible solutions are desirable solutions." 175 The resulting pluralism seems to be accepted not just as a negotiating reality given the need to find consensus in the face of divergent views among states but, to some extent, as a normative good in that it would allow different states to make their own choices and experiment with what works best. According to one negotiator, any reform framework should be "essentially flexible" with an "architecture" that would enable states "to adopt and implement relevant solutions . . . that fits their concerns based on their specific needs and interests." 176 In the words of another:

There is need for a coherent and flexible approach to the overall reform of ISDS allowing each state the choice of whether, and to what extent it wishes to adopt the relevant reform options. Different solutions should be envisaged to ensure the . . framework allows countries to retain the ability to implement the reforms of their choice. ${ }^{177}$

Negotiators are considering a flexible framework into which different reform options could be docked over time as additional protocols. ${ }^{178}$ One UNCITRAL negotiator likened this sort

\footnotetext{
${ }^{171}$ Submission from the Government of Thailand, supra note 86. See also Submission from the Government of Costa Rica, supra note 87 ("There is no one size fits all solution and, thus, flexibility should be at the core of any Working Group III discussion.”).

172 Submission from the Governments of Chile, Israel, Japan, Mexico and Peru: Possible Reform of InvestorState Dispute Settlement (ISDS), UNCITRAL Working Group III (Investor-State Dispute Settlement Reform), 38th Sess., Oct. 2019, UN Doc. A/CN.9/WG.III/WP.182, at https://undocs.org/en/A/CN.9/WG.III/WP.182. See also Submission from the Government of Costa Rica, UNCITRAL Working Group III (Investor-State Dispute Settlement Reform), 37th Sess., Apr. 2019, UN Doc. A/CN.9/WG.III/WP.164, at https://undocs.org/A/CN.9/ WG.III/WP.164 ("Because not all Member States have the same concerns, process should ensure enough flexibility so that they can choose to adopt the solutions and form that best suits their specific interests.").

${ }^{173}$ Singapore, Transcript of Audio from UNCITRAL Working Group III (ISDS Reform), 39th Sess., Oct. 9, 2020, 15:00-17:00.

${ }^{174}$ United States, Transcript of Audio from UNCITRAL Working Group III (ISDS Reform), 37th Sess., Apr. 3 , 2019, 10:00-13:00.

${ }^{175}$ Brazil, Transcript of Audio from UNCITRAL Working Group III (ISDS Reform), 39th Sess., Oct. 9, 2020, 15:00-17:00.

${ }^{176}$ Israel, Transcript of Audio from UNCITRAL Working Group III (ISDS Reform), 39th Sess., Oct. 9, 2020, 15:00-17:00.

177 South Africa, Transcript of Audio from UNCITRAL Working Group III (ISDS Reform), 39th Sess., Oct. 9, 2020, 15:00-17:00.

${ }^{178}$ Such a framework could be developed as a legal instrument or it could operate as a framing in the mind's eye of negotiators. A flexible framework creates a blueprint for thinking about what reform options exist and how they might fit together, but it could operate at the level of practice (i.e., a framework agreement is actually passed) or
} 
of framework to a "backbone" that different reforms could be plugged into or a computer operating system from which states could choose to download different apps:

[This potential] multilateral instrument [which] serve[s] as a basic foundation on which various plug-ins can be turned on and off strikes me . . . as being somewhat akin to developing an operating system of sorts like Android and the various substantive modules and options sitting on this backbone, comprising basically the different user applications, such as LinkedIn [or] WhatsApp, ... all of which one can choose to download and install or not, depending on our needs. ${ }^{179}$

Adaptability over time also matters to the UNCITRAL negotiators: "In addition to flexibility, any future discussions should be guided by adaptability." 180 Thus, a potential multilateral instrument "needs to be flexible enough in its architecture" to accommodate different choices now as well as "new or even future institutions that may be developed through this Working Group's processes, such as an advisory center or a multilateral investment court." 181 The negotiators are thinking across different time scales, too, with one observing that the Working Group needs "flexibility and adaptability in developing and implementing different solutions in the short, medium and long term." 182

At UNCITRAL, flexibility is valued at both the macro and the micro levels. At the macro level, the possibility of a multilateral instrument would offer "in-built flexibility" that "allow[s] each State the choice of whether and to what extent it wishes to adopt the relevant reform options." 183 Figure 3 illustrates a potential flexible framework with the three main blocks of reform currently being discussed: procedural instruments, dispute settlement institutions, and advisory support mechanisms. ${ }^{184}$ Several states, academics, and civil society groups have proposed different variations along similar lines. ${ }^{185}$

theory (i.e., it provides intellectual guidance only). It could also represent a temporary scaffold designed to assist the emergence of reforms until they are able to stand on their own. On frameworks versus scaffolds, see Ann Pendleton-Jullian, Coming of Age: From Frameworks and Theories of Change to Scaffolds for Ecologies of Change, in Cynefin, supra note 65, at 280, 284.

${ }^{179}$ Singapore, Transcript of Audio from UNCITRAL Working Group III (ISDS Reform), 39th Sess., Oct. 9, 2020, 15:00-17:00

${ }^{180}$ United States, Transcript of Audio from UNCITRAL Working Group III (ISDS Reform), 39th Sess., Oct. 9, 2020, 15:00-17:00.

${ }^{181}$ Singapore, Transcript of Audio from UNCITRAL Working Group III (ISDS Reform), 39th Sess., Oct. 9, 2020, 15:00-17:00.

${ }^{182}$ Costa Rica, Transcript of Audio from UNCITRAL Working Group III (ISDS Reform), 39th Sess., Oct. 9, 2020, 15:00-17:00.

${ }^{183}$ See Multilateral Instrument on ISDS Reform: Possible Reform of Investor-State Dispute Settlement (ISDS), UNCITRAL Working Group III (Investor-State Dispute Settlement Reform), 39th Sess., Mar.-Apr. 2020, UN Doc. A/CN.9/WG.III/WP.194, at https://undocs.org/en/A/CN.9/WG.III/WP.194.

${ }^{184}$ Roberts \& St John, supra note 149.

185 See, e.g., Submission from the Governments of Chile, Israel, Japan, Mexico and Peru: Possible Reform of Investor-State Dispute Settlement (ISDS), UNCITRAL Working Group III (Investor-State Dispute Settlement Reform), 38th Sess., Oct. 2019, UN Doc. A/CN.9/WG.III/WP.182, at https://undocs.org/en/A/CN.9/WG. III/WP.182. Matthew C. Porterfield \& Brooke Skartvedt Guven, Reforming the International Investment Regime Through a Framework Convention on Investment and Sustainable Development, UNCITRAL (Oct. 6, 2020), available at https://uncitral.un.org/sites/uncitral.un.org/files/media-documents/uncitral/en/a_framework_convention_on_investment.pdf; Stephan W. Schill \& Geraldo Vidigal, Designing Investment Dispute Settlement à la Carte: Insights from Comparative Institutional Design Analysis, 18 L. \& PRAC. INT'L CT. \& TRIB. 314 (2019). 


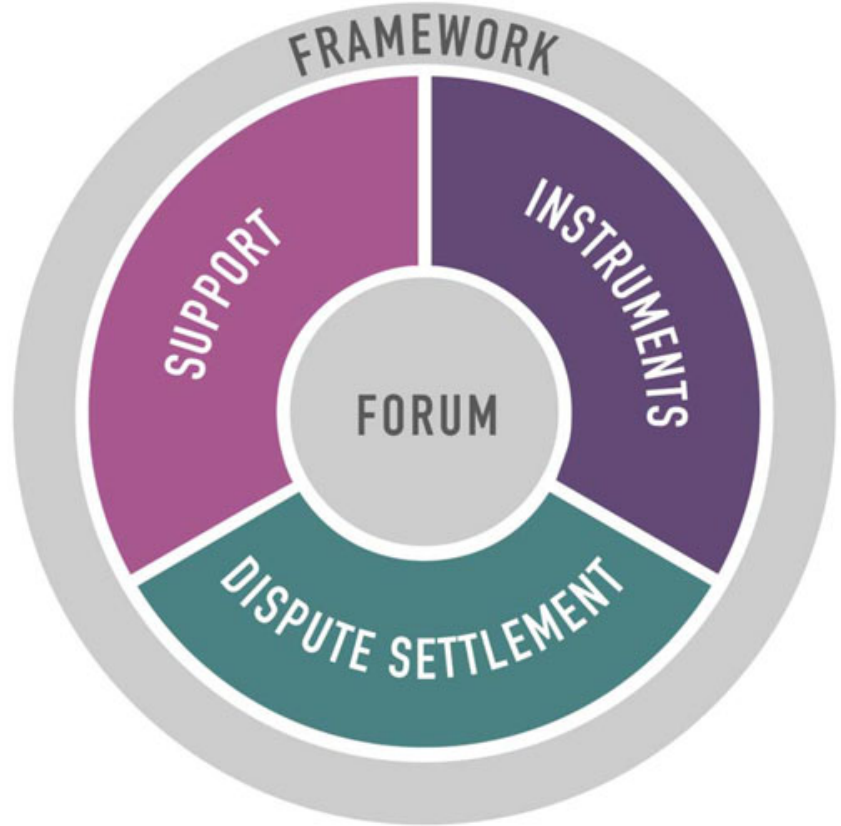

FIGURE 3. Visual representation of a potential flexible framework for ISDS reforms. (C) Anthea Roberts and Taylor St John

A state could be permitted to opt into procedural reforms but not structural ones, like a permanent court or appellate body. Within procedural reforms, states could opt into a code of conduct that would spell out the ethical obligations of adjudicators or into rules on the calculation and limits of damages or both. We illustrate this higher level of granularity in Figure 4 by showing categories of reform that could be developed under each main block. ${ }^{186}$

On the micro level, flexibility means giving states choice within particular reforms. For instance, within dispute settlement, negotiators may recognize multiple options, including domestic courts, alternative dispute resolution (including ombudsmen and conciliation or mediation), state-state dispute settlement, permanent adjudicators or a court of first instance, investor-state arbitration, and an appellate tribunal. Some might operate as alternatives, whereas others might be given jurisdiction in a certain sequence or over different issues. The European Union and its member states have endorsed an "open architecture" approach, recognizing that

[a] certain level of flexibility would ... need to be built into a standing mechanism. This would be necessary, for example, for countries that might want to use the standing mechanism for state-to-state dispute settlement, but which do not use investor-state dispute settlement in their agreements. It may also be the case that some countries may like to retain the flexibility to utilize only an appeal mechanism .... [T] he open architecture of 


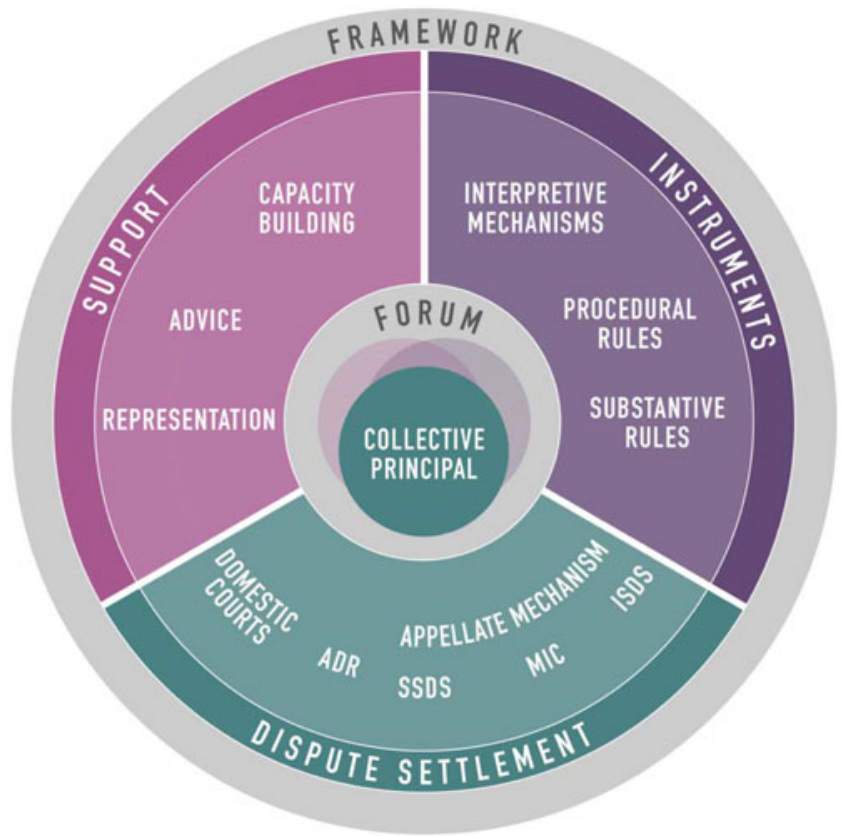

FIGURE 4. Detailed visual representation of a potential flexible framework for ISDS reforms. (C) Anthea Roberts and Taylor St John

the standing mechanism could be a way of providing for such flexibility for those countries. ${ }^{187}$

This sort of flexible and modular approach could enable states with divergent preferences, such as China, Brazil, and the European Union, to agree to a common framework. ${ }^{188}$

Flexible structures also leave room for pluralism and experimentation, which enables actors to learn from the experiences of others. ${ }^{189}$ Parallel reform experiments can generate useful evidence for such learning. For instance, Brazil (which has not ratified investment treaties) and South Africa (which terminated its treaties in favor of domestic court proceedings) have discussed their approaches at UNCITRAL. ${ }^{190}$ And the European Union and Canada, Singapore, Viet Nam, and Mexico are moving forward with the investment court system in their bilateral treaties, demonstrating experimentation with standing rosters and

187 Submission from the European Union and Its Member States, supra note 86, at 9. The notion of open architecture draws from Roberts, supra note 11.

${ }^{188}$ Submission from the Government of China, supra note 124; Submission from the European Union and Its Member States, supra note 86; Submission from the Government of Brazil: Possible Reform of Investor-State Dispute Settlement (ISDS), UNCITRAL Working Group III (Investor-State Dispute Settlement Reform), 38th Sess., Oct. 2019, UN Doc. A/CN.9/WG.III/WP.171, at http://undocs.org/en/A/CN.9/WG.III/WP.171. See also Anthea Roberts \& Taylor St John, UNCITRAL and ISDS Reform: China's Proposal, EJIL: TALK! (August 5, 2019), available at https://www.ejiltalk.org/uncitral-and-isds-reform-chinas-proposal.

${ }^{189}$ Miller \& Page, supra note 7, at 216; RoOM, supra note 64, at 33-37.

${ }^{190}$ Brazil, Transcript of Audio from UNCITRAL Working Group III (ISDS Reform), 34th Sess., Nov. 28, 2017, 14:00-17:00; South Africa, Transcript of Audio from UNCITRAL Working Group III (ISDS Reform), 34th Sess., Nov. 28, 2017, 14:00-17:00. 
permanent adjudicators that other states could copy bilaterally if they view the experiment as successful or scale up as the basis for a multilateral investment court. ${ }^{191}$

A flexible framework with regular meetings may encourage a balance to be struck between the goals of exploration and exploitation. ${ }^{192}$ Exploration furthers innovation, but too much time spent exploring can come at the cost of exploiting good solutions that have already been found. At UNCITRAL, negotiators may encourage variation to flourish and at the same time introduce centralized mechanisms to foster widespread replication of reforms already shown to work well. Mechanisms being considered for this include limiting the number of options in a multilateral instrument from which states can select and developing model clauses or tool kits of "best practices." 193 The plural is significant because reasonable expert views on "best practices" may differ. ${ }^{194}$ Flexible structures can function as a foundation for continuing experimentation and managed evolution.

\section{B. Balanced Content}

UNCITRAL negotiators frequently invoke the goal of "balance" for their investment treaties and reform proposals. They want to develop treaties and reforms that strike a suitable balance between investment protection and regulatory freedom. ${ }^{195}$ In discussing the introduction of counterclaims, they stress the balancing of states' ability to bring and to be the subject of claims. ${ }^{196}$ In appointing adjudicators, they call for states to balance their dual

191 The EU and Canada Adopt Rules Putting in Place the CETA Investment Court, Eur. Comm'N (Jan. 29, 2021), at https://trade.ec.europa.eu/doclib/press/index.cfm?id=2240.

${ }^{192}$ James G. March, Exploration and Exploitation in Organizational Learning, 2 OrG. ScI. 71, 71 (1991). On exploration and exploitation in the trade context, see Morin, Pauwelyn \& Hollway, supra note 4.

193 See Submission from the Government of Thailand, supra note 86 (model clauses could be developed on substantive provisions to "reduce the fragmentation of international investment law and ensure consistency, coherence, and predictability of arbitral awards"); Submission from the Governments of Chile, Israel, and Japan, UNCITRAL Working Group III (Investor-State Dispute Settlement Reform), 37th Sess., Apr. 2019, UN Doc. A/CN.9/WG.III/WP.163, at https://undocs.org/A/CN.9/WG.III/WP.163 (recommending developing "'best practices' toolkits ... that can build on the experience of Working Group participants to share as guidance"); Submission from the Governments of Chile, Israel, Japan, Mexico, and Peru: Possible Reform of InvestorState Dispute Settlement (ISDS), UNCITRAL Working Group III (Investor-State Dispute Settlement Reform), 38th Sess., Oct. 2019, UN Doc. A/CN.9/WG.III/WP.182, at 9, at https://undocs.org/en/A/CN.9/WG.III/WP. 182 (table compiling recent best practices from recent treaties).

${ }^{194}$ Snowden \& Boone, supra note 73.

195 See, e.g., Colombia, Transcript of Audio from UNCITRAL Working Group III (ISDS Reform), 39th Sess., Oct. 5, 2020, 15:00-17:00 ("We believe it is essential to strike a balance between attracting foreign investment and our holding the state's own interests.”); India, Transcript of Audio from UNCITRAL Working Group III (ISDS Reform), 37th Sess., Apr. 1, 2019, 15:00-18:00 ("I would like to address this issue of balance once again. ... We can partly address the issue of balance in our treaties to redrafting our treaties by having a balance of rights [between] investors and states. But the issue remains is that the balance is also in the hands of ISDS tribunals because of the expansive interpretation of the treaty continues. No matter how many times we reform or redraft our treaties the balance would not be achieved. So I think that balance is a concern that can be addressed by this Working Group.").

196 See, e.g., Chile, Transcript of Audio from UNCITRAL Working Group III (ISDS Reform), 39th Sess., Oct. 7, 2020, 11:00-13:00 (highlighting "the importance of a more balanced system, one in which States have different tools to deal with claims against them, including the possibility of counterclaims"); Peru, Transcript of Audio from UNCITRAL Working Group III (ISDS Reform), 39th Sess., Oct. 7, 2020, 11:00-13:00 ("It is important to establish a more balanced system, so that States have the necessary tools to enable them to ensure that investors do what they should. It's important to point out that the aim of the proposal is to have a more efficient and balanced system without inclining the balance disproportionately in favor of one party. If we have a framework in which States can make counterclaims, then there is greater equality and a better balance in costs."). 
interests as capital importers and capital exporters. ${ }^{197}$ In weighing the advantages of an appellate mechanism, they reflect on striking a balance between the virtues of correctness and consistency and those of cost and duration. ${ }^{198}$

Since the values pursued by complex designers often stand in tension with one another, the designers must find a balance between these values and then monitor or manage that balance as it evolves over time. As Jeffrey Dunoff and Mark Pollack point out, those who design judicial institutions "confront an interlocking set of potential tradeoffs" in pursuit of values like judicial independence, accountability, and transparency; they can maximize some values, but in doing so sacrifice others. ${ }^{199}$ Such trade-offs play out in iterative interactions involving states, adjudicators, and other actors.

In line with the trend toward management that we observe at UNCITRAL, we refer to these tensions and trade-offs between competing values as "polarities to be managed," drawing on Barry Johnson's idea from management literature. ${ }^{200}$ As Martin explains, these sorts of tensions "can't be fully solved but only balanced and managed." 201 To be successful over time, the balance initially struck between interdependent goals may need to be recalibrated in light of changes in conditions and perceptions. ${ }^{202}$

\section{Independence and Accountability}

One kind of polarity faced by UNCITRAL negotiators is between independence and accountability. This tension arises most clearly when negotiators discuss the selection and appointment of adjudicators since participants frequently frame the choice as requiring trade-offs between competing goals. "There are different interests in the appointment of adjudicators that pull in different directions," the chair says. "For instance renewable terms can strengthen accountability, but this measure also leads to a decrease in independence. Long terms can ensure independence, but reduce accountability."203

The UNCITRAL Secretariat likewise frames this issue as one of balance: "The Working Group may wish to note the need for a balance between independence and accountability, and the role of appointment procedures in this respect." 204 In support of this framing, the

${ }^{197}$ See, e.g., European Union, Transcript of Audio from UNCITRAL Working Group III (ISDS Reform), 40th Sess., Feb. 8, 2021, 15:00-17:00 (in making appointments for permanent adjudicators, states are "balancing their interest between ensuring their investors are protected in third countries against possible cases that may be brought against them").

198 See, e.g., Peru, Transcript of Audio from UNCITRAL Working Group III (ISDS Reform), Resumed 38th Sess., Jan. 20, 2020, 14:00-17:00 ("We think it would be important to have a balanced approach. . . . to ensure no additional costs or delays are generated."); Israel, Transcript of Audio from UNCITRAL Working Group III (ISDS Reform), Resumed 38th Sess., Jan. 20, 2020, 14:00-17:00 ("The question is how to balance" the "different concerns in the establishment of an appeal mechanism.").

199 Jeffrey L. Dunoff \& Mark A. Pollack, The Judicial Trilemma, 111 AJIL 225, 226 (2017).

200 Barry Johnson, Polarity Management: Identifying and Managing Unsolvable Problems xvii-xviii (2014)

${ }^{201}$ Roger Martin, The Design of Business: Why Design Thinking Is the Next Competitive Advantage 37 (2009). On the general need for balance in design thinking, see also 5-7 and 18-21.

202 Brian Emerson \& Kelly Lewis, Navigating Polarities: Using Both/And Thinking to Lead Transformation 7-11 (2019).

${ }^{203}$ Chair, Transcript of Audio from UNCITRAL Working Group III (ISDS Reform), 40th Sess., Feb. 8, 2021, 11:00-13:00.

204 Selection and Appointment of ISDS Tribunal Members: Possible Reform of Investor-State Dispute Settlement (ISDS), UNCITRAL Working Group III (Investor-State Dispute Settlement Reform), 40th Sess., 
Secretariat cites academic commentary to the effect that "designers of international courts face a series of trade-offs[;] . . . in particular, ... independence and accountability are features that are in conflict with one another: the more independent judges are the less accountable they will be, and vice versa." 205

States want adjudicators to be independent and accountable, but these interdependent goals cannot both be fully satisfied because they are in tension. As regards issues like renewable terms, UNCITRAL negotiators are considering how to calibrate this balance. Some (including representatives from the European Union and its member states) argue for movement toward permanent appointments and non-renewable terms to enhance independence; others (including representatives from the United States) warn that these reforms might be "so focused on independence that [they] may overshoot the mark and compromise other important objectives rather than balance them."206

This tension between independence and accountability also comes to the fore over other issues, such as whether and when an interpretation issued by the treaty parties might be binding on a tribunal. ${ }^{207}$ If the answer is always, even when the interpretation might resemble an amendment or apply to existing cases, accountability to the treaty parties is high. If the answer is never or only when the interpretation is clearly not an amendment and only with respect to future disputes, independence with respect to the treaty parties is high.

More broadly, the tension between these interdependent goals in dispute resolution finds expression in the work of scholars who frame international tribunals or judges as having "bounded discretion" or "constrained independence" in relation to governments. ${ }^{208}$ Sometimes the balance struck is closer to full independence (in which case tribunals or judges are depicted as "trustees") while at other times the balance is closer to full accountability (in which case tribunals are "agents"). ${ }^{209}$ The tension between the two roles partly arises due to the twin judicial functions of resolving disputes and interpreting the law, where tribunals are often cast as trustees with respect to dispute resolution (where individual treaty parties appear

Feb. 2021, UN Doc. A/CN.9/WG.III/WP.203, at https:/documents-dds-ny.un.org/doc/UNDOC/LTD/V20/ 065/89/PDF/V2006589.pdf?OpenElement.

205 The Secretariat referenced: Olof Larsson, Theresa Squatrito, Øvyind Stiansen \& Taylor St John, Selection and Appointment in International Adjudication: Insights from Political Science 4 (Acad. F. on ISDS, Concept Paper 2019/10).

${ }^{206}$ United States, Transcript of Audio from UNCITRAL Working Group III (ISDS Reform), 40th Sess., Feb. 8, 2021, 15:00-17:00.

${ }^{207}$ Roberts, supra note 126, at 179-225.

${ }^{208}$ Tom Ginsburg, Bounded Discretion in International Judicial Lawmaking, 45 VA. J. INT'L L. 631 (2004); Laurence R. Helfer \& Anne-Marie Slaughter, Why States Create International Tribunals: A Response to Professors Posner and Yoo, 93 CAL. L. Rev. 899, 917, 933-34 (2005).

${ }^{209}$ Karen J. Alter, Agents or Trustees? International Courts in Their Political Context, 14 Eur. J. INT'L Rel. 33, 3839 (2008); Karen J. Alter, Delegation to International Courts and the Limits of Re-contracting Political Power, in Delegation and Agency in International Organizations 312, 326-29 (Darren G. Hawkins, David A. Lake, Daniel L. Nielson \& Michael J. Tierney eds., 2006); Manfred Elsig \& Mark A. Pollack, Agents, Trustees, and International Courts: The Politics of Judicial Appointment at the World Trade Organization, 20 EuR. J. INT'L REL. 391 (2014). On the multiple motivations for delegating to courts or tribunals more generally, see Jacob Katz Cogan, Competition and Control in International Adjudication, 48 VA. J. INT'L L. 411, 416 (2008); Kenneth W. Abbott, Robert O. Keohane, Andrew Moravcsik, Anne-Marie Slaughter \& Duncan Snidal, The Concept of Legalization, 54 INT'L ORG. 401, 415-18 (2000); Kenneth W. Abbott \& Duncan Snidal, Hard and Soft Law in International Governance, 54 INT'L ORG. 421 (2000). 
before them as disputing parties) and agents with respect to interpretation (where tribunals share interpretive power with the treaty parties acting collectively).

Movements in the trade regime cast a shadow over the UNCITRAL discussions and show negotiators how systems sometimes lurch between competing goals. ${ }^{210}$ Under the General Agreement on Tariffs and Trade (GATT), panel reports would become legally binding only if they had been adopted in the GATT Council by consensus, resulting in high accountability and low independence when it came to the functions of resolving disputes and interpreting the law. Recognizing the problems arising from this lack of independence, states went to the opposite pole in creating the WTO, under which panel reports became legally binding unless there was a consensus not to adopt them ("reverse consensus"). ${ }^{211}$ Panel reports were subject to appeal to the WTO Appellate Body while authoritative interpretations could, in theory, be adopted by a three-quarter majority vote of the WTO General Council. In practice, however, this threshold was high enough that interpretations by the treaty parties were never adopted, so the balance in both dispute resolution and interpretation shifted toward independence over accountability. ${ }^{212}$

The movement between these goals over time can be captured by what Johnson calls a "polarity map" which shows the movement in sentiments or perceptions (y-axis) about the advantages and disadvantages of moving toward different interdependent goals ( $\mathrm{x}$-axis) (see Figure 5). The GATT system began in the top right hand quadrant with the advantages that come with treaty party control before some members experienced some of the disadvantages that came with this in terms of lack of independence and impartiality, tipping their perceptions of the system into the bottom right hand quadrant. From there, they looked up to the positives of the other pole in the top left hand quadrant, redesigning the institution to take advantage of the positives of independence. Too much independence then caused concern in the United States, as it meant that it lacked an ability to control and correct WTO decisions, resulting in US sentiment tipping into the bottom left hand quadrant. These concerns led some U.S. officials to argue in favor of returning to GATT-style dispute resolution where treaty parties would have greater control over judicial decision-making. ${ }^{213}$ The resulting infinity curve captures the cyclical movement in sentiment and institutional design over time.

\footnotetext{
210 The trade regime casts a shadow over appointment discussions in particular; on the trade-off between independence and accountability with respect to appointments to the WTO Appellate Body, instead of interpretations by panels, see Elsig \& Pollack, supra note 209; Dunoff \& Pollack, supra note 199 at 260-71; John Maton \& Carolyn Maton, Independence Under Fire: Extra-Legal Pressures and Coalition Building in WTO Dispute Settlement, 10 J. InT'L Eco. L. 317 (2007); Jennifer A. Hillman, Independence at the Top of the Triangle: Best Resolution of the Judicial Trilemma?, 111 AJIL UnBound 364-68 (2017)

${ }^{211}$ Peter van den Bossche, From Afterthought to Centrepiece: The WTO Appellate Body and Its Rise to Prominence in the World Trading System, in THE WTO AT TeN 289-325 (Giorgio Sacerdoti, Alan Yanovich \& Jan Bohanes eds., 2006).

212 Claus-Dieter Ehlermann \& Lothar Ehring, The Authoritative Interpretation Under Article IX:2 of the Agreement Establishing the World Trade Organization: Current Law, Practice and Possible Improvements, $8 \mathrm{~J}$. InT'L Econ. L. 803 (2003); Nicolas Lamp, Arrested Norm Development: The Failure of Legislative-Judicial Dialogue in the WTO (unpublished manuscript on file with authors).

${ }^{213}$ For instance, then U.S. Trade Representative Robert Lighthizer called for the WTO's dispute-settlement system to be totally rethought and returned to GATT-style panels. See Robert E. Lighthizer, How to Set World Trade Straight, WALL ST. J. (Aug. 20, 2020), at https:/www.wsj.com/articles/how-to-set-world-trade-straight11597966341.
} 


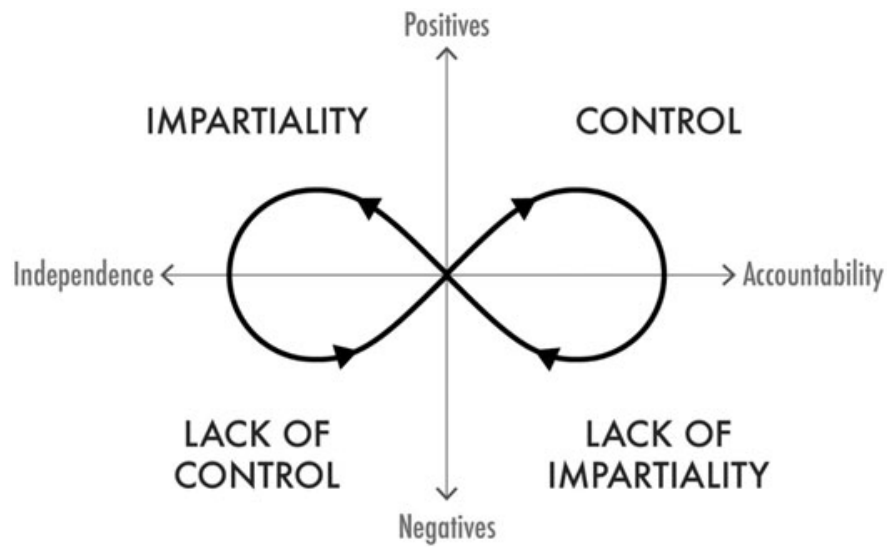
John

FIGURE 5. Mapping the polarity between independence and accountability. (C) Anthea Roberts and Taylor St

\section{Centralization and Decentralization}

Negotiators at UNCITRAL also debate the benefits of centralization and decentralization. Those who favor introducing an investment court or appellate body aim at recalibrating the balance of the system toward greater centralization. They often emphasize the need to ensure greater consistency, coherence, predictability, or efficiency in dispute resolution, qualities that they argue will be facilitated by the development of a court with a stable group of judges and an appellate system and that will foster a more consistent body of quasi-precedent. ${ }^{214} \mathrm{By}$ contrast, negotiators who oppose the introduction of a court or appellate mechanism point to the problems of undermining diversity and state choice, and entrenching consistency at the expense of correctness and innovation. ${ }^{215}$

Centralization is associated with increased consistency and efficiency, and decentralization with increased diversity and experimentation, which give rise to greater dynamism. Centralization's positives of increased consistency and efficiency often come at the cost of lost dynamism and insufficient flexibility to ensure adequate variation and redundancy. On the flip side, decentralization's positives of dynamism and resilience often come at the cost of increased inconsistency and inefficiency.

Figure 6 shows a polarity map of these interdependent goals. Starting in the bottom left quadrant, one can see the disadvantages that emanate from too much decentralization

${ }^{214}$ Submission from the Government of China, supra note 124 (observing that establishing a permanent appeal mechanism would "be an important factor in promoting application of the rule of law to the settlement of disputes between investors and states" after noting that numerous inconsistencies in awards rendered by arbitration tribunals and uncertainty of arbitral results "have seriously affected the expectations of the parties involved" and that arbitration alone "clearly cannot meet the requirements for realizing the rule of law"). See also Submission from the European Union and Its Member States, supra note 86, at 9-12.

${ }^{215}$ United States, Transcript of Audio from UNCITRAL Working Group III (ISDS Reform), Resumed 38th Sess., Jan. 20, 2020, 10:00-12:30 (observing that "searching for consistency where it may in fact, not need to apply may not be the best objective for strengthening the legitimacy and enhancing the correctness of decisions"); Japan, Transcript of Audio from UNCITRAL Working Group III (ISDS Reform), Resumed 38th Sess., Jan. 20, 2020, 14:00-17:00 (noting that "there are real risks" to the introduction of an appellate mechanism, including pursuing coherence and consistency to the extent it undermines correctness). 


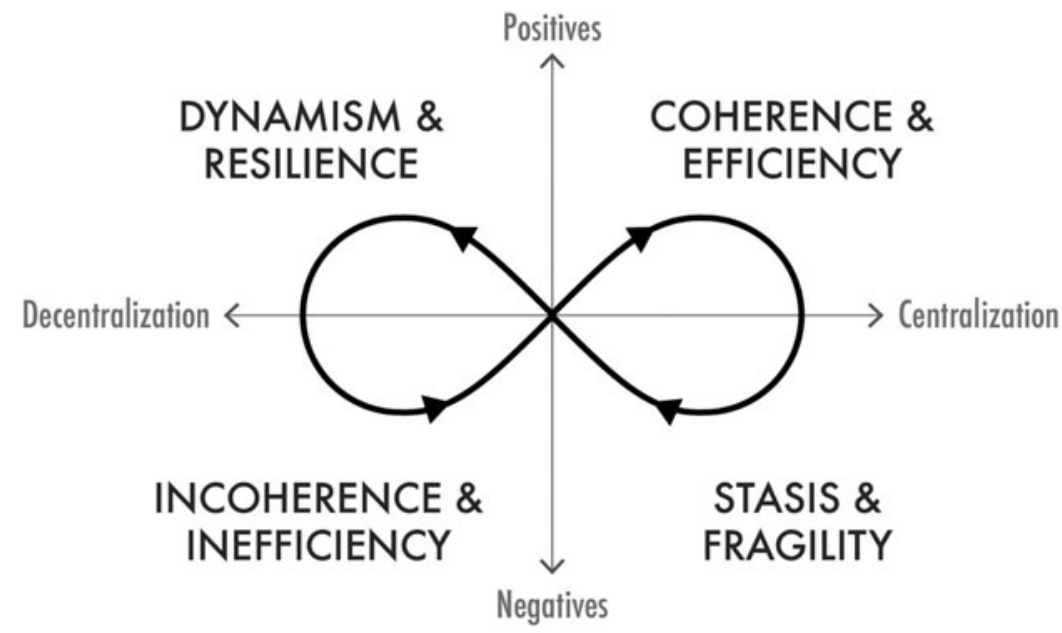

FIgURE 6. Mapping the polarity between centralization and decentralization. (C) Anthea Roberts and Taylor St John

(inconsistency and inefficiency), which often lead actors facing these problems to look up to the top right quadrant, which reflects the advantages of centralization (consistency and efficiency). But as actors increasingly move toward centralization, they are likely to experience more of the negatives of that approach by dropping into the bottom right quadrant (stasis and fragility), which will make them look up to the positives of decentralization in the top left quadrant (dynamism and resilience), resulting in a cyclical infinity curve movement.

Any movements in one direction entail more positives from one pole and more negatives from the other. The emergent design question thus becomes not which pole is better but, rather, how can one get more of the positives from one pole without losing many of the positives from the other? 216 Whatever balance is struck between the above goals might also require periodic recalibration.

\section{Adaptive Management Processes}

The UNCITRAL negotiators spend a lot of time discussing how to manage various aspects of the system. Should third-party funders be permitted in the system and, if so, what transparency rules should be applied to their role? Should an early dismissal procedure be adopted to deal with frivolous claims? Do small and medium-sized enterprises need more support or different rules to ensure that they can access the system? Are case proceedings too long and costly and, if so, what could be done about it? Are damages awards too high or unpredictable and, if so, what rules could the negotiators adopt to guide their future formulation? Although these might look like individual concerns, they can be tied together as attempts to develop adaptive processes to manage the investment treaty system over time.

UNCITRAL negotiators discuss how to build mechanisms to enable adaptive management. For instance, while discussing a proposed advisory center, one negotiator observed: "There's likely to be an evolution in how the center functions. ... It may be that we have to make some

\footnotetext{
${ }^{216}$ EMERSON \& LeWIS, supra note 202, at 148-50.
} 
initial decisions at a certain moment in time but we need to have the flexibility to be able to adjust . . . it's useful to think about this project not just in static terms but also how it may evolve and ... we don't want to be coming back and revising an international treaty too frequently if we can avoid it so we need to think about mechanisms within this [center] to try to manage these issues." 217 Adaptive management requires the creation of forums and processes for monitoring and intervention, which moves complex designers past episodic (re)design and toward continuous calibration.

Forums for monitoring and intervention have become increasingly common in international law, spreading from multilateral environmental agreements to other fields that also cope with complexity and change. Robin Churchill and Geir Ulfstein first charted the growth of these forums, which they called "autonomous institutional arrangements." They noted that these arrangements suggested "a distinct and different approach to institutionalized collaboration between states, being both more informal and more flexible" than previous arrangements. ${ }^{218}$ At the WTO, various committees, working parties, and review bodies generate and disseminate information, partly transforming the Organization into a forum for "the supervision, monitoring, and management of (certain aspects of) the international trading system." ${ }^{219}$ Many recent investment treaties establish joint committees to monitor implementation and exchange information. ${ }^{220}$

\section{Monitoring Stocks and Flows}

Monitoring stocks and flows encourages actors to think systemically and to identify whether corrective interventions are necessary. Stocks and flows are concepts that come from systems thinking: as certain elements flow into or out from a system, the stock of that element in the system may rise or fall, with the potential to cause systemwide changes, which can be non-linear if certain critical thresholds are breached. ${ }^{221}$ For instance, if discontent with the system builds up (high stocks), relatively small challenges (low flows) may bring the system closer toward a tipping point in which officials feel significant pressure to enact more far-reaching change. At the same stage, even if discontent with the system is low (low stocks), it may reach or surpass tolerance levels in the event of a large shock (high flows). Complex designers can exercise agency in this process, monitoring and intervening in stocks and flows by reference to their understanding of how these affect the broader dynamics within the system and in the shadow of potential tipping points.

Stocks can refer to tangible elements like the total number of treaties in effect or cases that have been filed or are ongoing. Flows can refer to the rate of new treaties being signed or existing ones lapsing or being terminated or the number of new cases being brought and existing

\footnotetext{
${ }^{217}$ European Union, Transcript of Audio from Informal Online Meeting on the Establishment of an Advisory Center, June 15, 2021, 13:00-15:00.

${ }^{218}$ Robin Churchill \& Geir Ulfstein, Autonomous Institutional Arrangements in Multilateral Environmental Agreements: A Little-Noticed Phenomenon in International Law, 94 AJIL 623 (2000).

219 Andrew Lang \& Joanne Scott, The Hidden World of WTO Governance: A Rejoinder to Richard H. Steinberg, 20 EUR. J. INT'L L. 575, 576 (2009).

220 Tarcisio Gazzini, Nigeria and Morocco Move Towards a "New Generation" of Bilateral Investment Treaties, EJIL:TALK! (May 8, 2017), at https://www.ejiltalk.org/nigeria-and-morocco-move-towards-a-new-generation-ofbilateral-investment-treaties.

221 See STERMAN, supra note 153, at 102, 210-11.
} 
ones being resolved. Both can also refer to intangible elements like public or state support for the system. UNCITRAL negotiators show a desire to monitor and regulate certain flows and stocks within the system. Unlike arbitrators, who are tasked with interpreting and applying a treaty in a single case, UNCITRAL serves as a forum in which states can consider these issues at a systemic level. Negotiators agree on the need for tools to monitor and manage certain stocks and flows. They ask: which stocks and flows most urgently require monitoring and which tools should states use to manage them?

Many of the proposed reforms reflect a desire to tighten the jurisdictional tap to stem the flow of cases. One clear example is the discussion of rules around creating early dismissal procedures for frivolous claims. ${ }^{222}$ Reforms seeking to limit liability (e.g., treaty provisions stating that generally applicable measures taken in the public interest will not typically constitute expropriation) or some reforms on damages (e.g., switching damages calculations from expectation damages to reliance damages or providing a cap on damages) also represent efforts to tighten the tap in terms of liability and quantum. By contrast, efforts to ensure greater access to investment treaty arbitration for small and medium enterprises represent efforts to loosen the jurisdictional tap.

It is also possible to reduce the flow of cases by looking at elements in the system that might be driving flow rates indirectly. We see this approach in negotiators' search for more information about third-party funding. Some states have expressed concern that such funding incentivizes cases to be filed in the hope of high damages awards; others warn that prohibiting third-party funding might negatively affect the ability of small and medium-sized enterprises to bring cases. Negotiators are considering reforms to require disclosure of third-party funding, which would generate more evidence about its role in the system that could then be used in deciding how to address this funding. ${ }^{223}$

Stocks and flow rates can also apply to intangible elements of the system, such as public acceptance. The filing of a controversial, high-profile case, like Philip Morris against Australia or Vattenfall against Germany, may significantly alter the stock of support for the system. For instance, public discontent with ISDS grew in the years leading up to the negotiations of the Transatlantic Trade and Investment Partnership (TTIP) between the United States and the European Union until the negotiations broke down, leading the European Union to formulate the court-based proposal it then took to UNCITRAL. Monitoring public perceptions and systemic legitimacy therefore also forms part of UNCITRAL negotiators' work, as does intervening when appropriate.

\section{Intervening in Feedback Loops}

Although feedback loops are often assumed to emerge and run automatically in complex systems (e.g., without being planned by designers), designers may be able to anticipate such loops and use them in pursuit of their long-term strategic aims. Designers can build in positive

\footnotetext{
${ }^{222}$ Security for Cost and Frivolous Claims: Possible Reform of Investor-State Dispute Settlement (ISDS), UNCITRAL Working Group III (Investor-State Dispute Settlement Reform), 39th Sess., Mar.-Apr. 2020, UN Doc. A/CN.9/WG.III/WP.192, at https:/documents-dds-ny.un.org/doc/UNDOC/LTD/V20/003/85/PDF/ V2000385.pdf?OpenElement.

223 Third-Party Funding_-Possible Solutions: Possible Reform of Investor-State Dispute Settlement (ISDS), UNCITRAL Working Group III (Investor-State Dispute Settlement Reform), 38th Sess., Oct. 2019, UN Doc. A/CN.9/WG.III/WP.172, at https://undocs.org/en/A/CN.9/WG.III/WP.172.
} 
feedback loops, which amplify a particular approach, and negative feedback loops, which have a dampening effect. By intervening at key leverage points, actors can help steer the system's trajectory. ${ }^{224}$ They can do this with an eye to their overarching goals, such as seeking resilience or transformation of the system.

On a micro level, one feedback loop of interest to UNCITRAL negotiators is treaty interpretation. Decisions by arbitral tribunals do not command strict precedential value but, in practice, they are often cited as authority by later tribunals. This progression produces a positive feedback loop in which particular interpretations gain momentum and eventually become (relatively) settled jurisprudence. ${ }^{225}$ The process is subject to negative feedback loops within the course of arbitration: another tribunal may disagree with the initial interpretation and set forth a contrary interpretation. The negative loop may also be picked up in future cases, which would either fully or partially balance out the momentum of the original positive feedback loop and potentially create a sufficient feedback loop in its favor to establish a new interpretation. The more a specific interpretation is accepted, the more likely it is to be followed by other tribunals.

Tribunals, however, share interpretive power with treaty parties, and states can endorse or repudiate interpretations of their treaties by amending existing treaties, entering into new treaties, or using drafting techniques to better guide interpretation of their treaties. ${ }^{226}$ When states act to endorse an interpretation developed by a tribunal or tribunals, their action contributes to a positive feedback loop. When they repudiate such an interpretation, their action produces a negative feedback loop. At UNCITRAL, states treat the possibility of joint interpretations as a key leverage point for intervening in the system. As one delegation explains, joint interpretations "narrow the scope of interpretive discretion of tribunals and thus minimize unintended and contradictory interpretations in ISDS proceedings." 227

On a macro level, different UNCITRAL negotiators appear to have different goals in managing feedback loops, including aiming for resilience in the existing system or transformation to a new system. If negotiators want to promote resilience in the existing system, they can use feedback mechanisms to take small-scale corrective or confirmatory actions that will stabilize the system or allow it to adapt while continuing to function; the aim is to prevent building to an unstable tipping point that might result in more abrupt change. By contrast, if negotiators want to transform the system, they can make interventions that strengthen destabilizing feedback loops or they could use destabilizing feedback loops to undermine an existing institution, and then build stabilizing ones to reinforce a new institution.

As complex systems are dynamic and unpredictable, governance systems regulating them must be adaptive if they are going to cope with changes over time, whether new interpretations by tribunals or increased concern by the public. To permit ongoing learning and

${ }^{224}$ RoOM, supra note 64, at 238-39.

225 Wolfgang Alschner, Investment Arbitration and State-Driven Reform: New Treaties, Old Outcomes (manuscript on file with the authors); STONE SweET \& Grisel, supra note 94, at 119-70.

${ }^{226}$ Jeremy K. Sharpe, From Delegation to Prescription: Interpretive Authority in International Investment Agreements, in By Peaceful Means: International Adjudication and Arbitration (C. Brower, et al. eds., 2022) (observing states increasingly guiding interpretation of their treaties through interpretive guidelines, interpretive clarifications, interpretive indicators, and interpretive markers).

${ }^{227}$ Iran, Transcript of Audio from UNCITRAL Working Group III (ISDS Reform), 39th Sess., Oct. 8, 2020, 15:00-17:00. 
adaptation, designers can create forums where relevant actors can meet on a regular basis to monitor the system and make interventions to shape its evolution. As we have reflected during the UNCITRAL process:

States waking up to the importance of a forum is a subtler, longer-term development, but it may be the most important thing happening in this Working Group. A hub where they meet regularly, learn from one another, and deliberate reform options opens up new possibilities for joint action and gives new impetus to domestic action. A hub focuses minds on potential problems in a forward-looking way. ${ }^{228}$

Time will tell if this sort of hub develops in or beyond UNCITRAL. If so, it suggests that negotiators see their engagement with the system as one of ongoing adaptive management, rather than just episodic redesign.

\section{Conclusion}

In this Article, we have argued that there is a logic and coherence underlying what we observe at UNCITRAL that can be illuminated by applying insights from complexity theory. We conclude in this section by comparing expectations about where UNCITRAL's evolutionary approach might lead over time and by asking if the emergent design principles we see here are playing out in other complex governance systems like those in climate and trade.

As noted above, expectations about where the evolutionary approach adopted at UNCITRAL will lead vary widely. Some academics and civil society observers emphasize that small-scale corrective action may lock in the existing system. ${ }^{229}$ For instance, BartJaap Verbeek argues that " $[\mathrm{t}]$ he UNCITRAL process . . . runs a real risk of producing middle-ground solutions that will fail to address the fundamental flaws of the ISDS system and will only further institutionalise and re-legitimise the system." 230 Likewise, Lise Johnson and Lorenzo Cotula note that the prioritization of pragmatism and flexibility "may well help fix certain flaws affecting present-day ISDS. But it does not allow a more open discussion about designing an international system ... that responds to the social, environmental and economic challenges the world faces today." 231 These actors see an incremental approach as dissipating momentum for more far-reaching reform or termination programs.

Other actors emphasize that the evolutionary approach might be transformative. To some negotiators, the current discussions are setting in motion processes that may build momentum and eventually lead to outcomes not currently on the agenda, including substantive reform. This, after all, is the way UNCITRAL has operated in the past: starting with a relatively restricted mandate, building legitimacy gradually, and incrementally going deeper and more broadly into an issue area. ${ }^{232}$ Thus, reflecting on the process, one negotiator noted: "The interesting thing about UNCITRAL is that it has triggered... a more general debate on

\footnotetext{
${ }^{228}$ Roberts \& St John, supra note 99.

${ }^{229}$ Ksenia Polonskaya, Metanarratives as a Trap: Critique of Investor-State Arbitration Reform, 23 J. INT'L ECON. L. 949 (2020).

${ }^{230}$ Verbeek, supra note 13.

231 Johnson \& Cotula, supra note 13.

232 Block-Lieb \& Halliday, supra note 21, at 80-91.
} 
the regime overall," pointing out that it had prompted discussions about how substantive rulemaking fits with dispute resolution and the need for an advisory center to better support developing states. ${ }^{233}$

We do not know what will eventuate from the UNCITRAL reform process and while we believe emergent design approaches have many benefits, it is important to note that these approaches also have downsides. One important concern is that not all actors have the resources to engage effectively over a long time span. Processes of incremental change are "generally difficult for all but the most attentive political actors to anticipate, monitor, and influence. These features advantage organized interests with long time horizons and the resources to play the long game." 234 Using evolutionary approaches in governance raises "fundamental questions about who has the power to shape outcomes over the long term."235 Another concern is that flexibility may preserve state sovereignty in theory, while making it more likely that, in practice, developing states will have to adopt multiple models in line with powerful actors' preferences. Flexibility, like all values, has drawbacks.

To what extent do the concepts of complex designers or emergent design apply elsewhere? It is likely that would-be designers perceive growing complexity in a variety of issue areas today, and complexity theory is already being used to make sense of institutional dynamics in many international fields, from peacekeeping to tax. ${ }^{236}$ If we return to the characteristics that shape would-be designers' perceptions of complexity sketched above-agents, formal structures, informal practices, issue area dynamism, and the distributions of power and preferences among would be-designers - it is easy to see why actors in many areas might perceive themselves to be acting within systems that are becoming increasingly complex.

For instance, the climate is a dynamic issue area, with new scientific information and changing political positions emerging frequently. Thousands of agents, if not more, are involved in climate governance, from small NGOs to large corporations, and from village authorities to central banks and presidents. The existing formal architecture is expansive and diverse, with authority weakly centralized. Varied informal structures (such as production practices) exist at local, national, and international scales, many of which may be difficult to dislodge. Meanwhile, the power to act is widely distributed; no single actor enjoys the ability to insist on its approach as the one and only solution. Would-be designers subscribe to starkly different approaches. By any of these measures, climate governance is more complex than the investment treaty system.

It is unlikely a coincidence, then, that the emergent design approach we see incipient at UNCITRAL has been taken much farther in climate governance. After more traditional attempts at multilateral cooperation failed or generated very limited results in climate change, emergent design principles were employed. More flexible and adaptive treaty structures like the Paris Agreement emerged and the role of the UN Framework Convention on Climate

233 The Debate on ISDS Reform, Main Narratives and Tensions Moderated by Dr. Inga Martinkute, Vilnius University, YouTube (May 13, 2021), at https://www.youtube.com/watch?v=-6pRUzoIrdI (Comment by Colin Brown at 52:00).

${ }^{234}$ Jacob S. Hacker, Paul Pierson \& Kathleen Thelen, Drift and Conversion: Hidden Faces of Institutional Change, in Advances in Comparative-Historical Analysis 181 (James Mahoney \& Kathleen Thelen eds., 2015).

235 Id. at 182.

${ }^{236}$ On peacekeeping, see Cedric de Coning, Adaptive Peace Operations: Navigating the Complexity of Influencing Societal Change Without Causing Harm, 27 InT'L PeAceKeEPING 836 (2020). On tax, see Vincent Arel-Bundock, The Unintended Consequences of Bilateralism: Treaty Shopping and International Tax Policy, 71 INT'L OrG. 349 (2017). 
Change (UNFCCC) shifted "from implementer to coordinator" of structures that permit ongoing monitoring and intervention. ${ }^{237}$ The Paris Agreement is not streamlined; it is modular and embraces diverse tools and approaches. The balance between centralization and decentralization has shifted, as has the centrality of the UNFCCC. ${ }^{238}$ It was designed with adaptive actors in mind, as a "catalytic institution" that works to redirect actors' preferences and strategies toward cooperative outcomes over time. ${ }^{239}$

The Paris Agreement is far from perfect. The complex designers behind it may not find the Paris Agreement optimal or likely to solve the problem of climate change. But it may have been the best that could be done in the circumstances and it is delivering climate change mitigation and other goals in ways and at scales that previous interventions were not. Modest results likely hold true of emergent design generally: it does not generate an optimal, single solution to a particular problem, but it may succeed to some degree in situations where other, more streamlined, elegant designs fail outright.

As negotiators and other participants perceive their issues areas to grow in complexity, we may be seeing moves away from streamlined designs toward more emergent designs even in issue areas where authority has traditionally been more centralized. In these issue areas, like trade law, some negotiators may find themselves becoming complex designers reluctantly. In the early 1990s, the creation of the WTO streamlined and centralized existing trade agreements alongside a new, stronger dispute resolution procedure. ${ }^{240}$ One reason it was possible to create such streamlined architecture was the distribution of power and preferences among would-be designers at the time: the powerful Quad states (the United States, the European Union, Canada, and Japan) had broadly similar preferences and were able to propose their approach as a fait accompli.. ${ }^{241}$

Although the WTO's design produced greater efficiency, consistency, and predictability, its streamlined nature and resistance to amendment also made it less adaptable to changing circumstances. It became difficult for WTO members to agree on new rules or other adaptations, so much of the system's dynamism moved to dispute settlement. While the United States spearheaded the WTO's creation, it has also led the backlash against the Organization because of unintended consequences that resulted, including from interpretations it did not agree with and the empowerment of key emerging states like China. ${ }^{242}$ One of the U.S. negotiators who had a key role in procuring the WTO's streamlined design is now convinced that

${ }^{237}$ Jonathan Kuyper, Heike Schroeder \& Björn-Ola Linnér, The Evolution of the UNFCCC, 43 AnN. Rev. Env'T \& RES. 343 (2018).

${ }^{238} I d$. at 362 .

239 Thomas Hale, Catalytic Cooperation, 20 Glob. Envtl. Pol. 73 (2020).

${ }^{240}$ Before the creation of the Organization, John Jackson had criticized the "increasingly complex" relationship among existing agreements, noting "Such complexity ... will make it harder for the general public to understand the GATT system, perhaps resulting in less public support for that system over time. This complexity will hurt those countries that cannot devote additional governmental expertise to GATT representation problems. In addition, such complexity inevitably will give rise to a variety of legal disputes among GATT parties." JOHN H. JACKSON, RESTRUCTURING THE GATT SYSTEM 25 (1990).

${ }^{241}$ For an explanation and analysis of this movement, see Nicolas Lamp, The Club Approach to Multilateral Trade Lawmaking, 49 VAND. J. TRANSNAT'L L. 107, 165-81 (2016).

${ }^{242}$ On interpretations the United States did not agree with and the resulting Appellate Body appointments crisis, see Bernard Hoekman \& Petros C. Mavroidis, Burning Down the House? The Appellate Body in the Centre of the WTO Crisis (Eur. Uni. Inst., Robert Schuman Centre for Advanced Stud., Global Governance Programme Working Paper No. RSCAS 2019/56, 2019). On the empowerment of emerging states, see Shaffer, supra note 28; Kristen Hopewell, Breaking the WTO: How Emerging Powers Disrupted the Neoliberal Project (2016). 
"[w] e never should have done it" 243 — it "wrecked what had been a pretty good system" before the WTO was created. ${ }^{244}$

As negotiations at the WTO experience periods of stasis, and especially after the WTO Appellate Body ground to a halt, trade negotiators find themselves in the role of complex designers. The system they face today is more complex than it was in the 1990s; power is distributed more widely, preferences among would-be designers vary starkly, more agents are involved, new challenges keep emerging (from digital trade issues to trade and environment and beyond), and the formal trade architecture is increasingly decentralized. We can understand the calls to encourage smaller groups of like-minded states to enter into plurilateral agreements or efforts to keep dispute settlement at the WTO operating through arbitration-makeshift and imperfect as they seem to many observers-as nascent steps toward emergent design. ${ }^{245}$

These climate change and trade examples demonstrate the potential for the analysis in this Article to serve as a framework for understanding design across a wide range of global governance domains. In particular, the insights in this Article seem apposite in issue areas that are fast-changing, with many agents constantly engaging in informal practices within a decentralized formal architecture, and in which power is distributed among multiple actors who disagree on the way forward. As we survey the challenges ahead, the overlapping existing governance structures, and the ongoing geopolitical rebalancing in favor of greater multipolarity, institutional design in complexity seems likely to characterize our future for some time. These developments make understanding complex designers and emergent design principles both timely and important.

${ }^{243}$ See Andrew Stoler Correspondence, referenced in Lamp, supra note 241, at 183.

${ }^{244}$ Andrew L. Stoler, Breaking the Impasse: A Critical Mass Approach to Multilateral Trade Negotiations, CPP Symp. on the Future of the Multilateral Trade Sys.

${ }^{245}$ See, e.g., European Commission, Annex to the Trade Policy Review Communication-Reforming the WTO: Towards A Sustainable and Effective Multilateral Trading System, COM(2021) 66 FINAL (Feb. 18, 2021), available at https://trade.ec.europa.eu/doclib/docs/2021/february/tradoc_159439.pdf; Bernard Hoekman \& Charles Sabel, Plurilateral Cooperation as an Alternative to Trade Agreements: Innovating One Domain at a Time (Eur. Uni. Inst., EUI Working Paper RSC 2021/01, 2021), at https://hdl.handle.net/1814/69578. 